UDK: 343.14 (497.6)

Pregledni znanstveni rad

Primljen: 20. travnja 2018.

Prihvaćen: 2. rujna 2018.

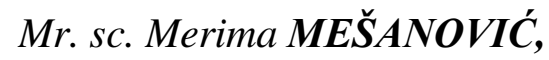

tužiteljica Kantonalnog tužilaštva Unsko-sanskog kantona

merimamesanovic@gmail.com

\title{
INSTITUT NEZAKONITIH DOKAZA U KRIVIČNIM POSTUPCIMA U BOSNI I HERCEGOVINI SA OSVRTOM NA UPOREDNO PRAVO
}

Sažetak: U radu se razmatra institut nezakonitih dokaza u krivičnom zakonodavstvu u Bosni $i$ Hercegovini s teorijskog, zakonskog i praktičnog aspekta. Nakon teorijskog obrazlaganja pojma „,nezakonitih dokaza“, analiziraju se pozitivnopravne odredbe o nezakonitim dokazima u zakonima o krivičnim postupcima u Bosni $i$ Hercegovini, te pravne posljedice njihove upotrebe uz uporednu analizu instituta nezakonitih dokaza u najznačajnijim pravnim sistemima evropsko-kontinentalnog sistema i anglosaksonskog pravnog kruga (SAD). U radu se ukazuje i na dva najznačajnija teorijska i uporedna sistema izdvajanja nezakonitih dokaza - apsolutni $i$ relativni sistem izdvajanja nezakonitih dokaza. U zadnjem poglavlju rada dat je opsežan pregled prakse Evropskog suda za ljudska prava i prakse Ustavnog suda Bosne i Hercegovine po pitanju nezakonitih dokaza.

Normativnom analizom domaćih pravnih normi na kojima je utemeljen institut nezakonitih dokaza, uz utvrđivanje njihovog tačnog značenja i smisla, te paralelnim kompariranjem sa uporednim sistemima uz osvrt na dosadašnju sudsku praksu po pitanju pravnih posljedica upotrebe nezakonitih dokaza u krivičnom postupku, autorica zaključno, a što je i cilj rada, iznosi svoj stav i ukazuje na nužnost promjene zakonske regulative kada je u pitanju apsolutni oblik izdvajanja nezakonitih dokaza i normiranje tzv. relativnog izdvajanja koje se temelji na razmjernosti, što je u skladu i sa dominantnim kretanjima u razvoju ovog instituta u uporednom pravu.

Ključne riječi: nezakoniti dokazi, apsolutno i relativno izdvajanje nezakonitih dokaza, razmjernost, uporedno pravo. 


\section{Uvod}

Pojam nezakonitih dokaza izaziva mnoge teorijske rasprave i jedan je od centralnih instituta savremenog krivičnog postupka, a kompleksnost tog problema spada u najznačajnija pitanja krivičnog procesnog prava.

Razlog tome ogleda se u dvojakom cilju i svrsi krivičnog postupka. Savremeni krivični postupak mješovitog tipa, kao i onaj akuzatorskog tipa nastoje održati ravnotežu između dva osnovna suprostavljena zahtijeva svakog društva, i to:

- zahtjeva za funkcionalnošću kažnjavanja počinioca krivičnih djela s jedne strane i

- s druge strane, pak, zahtjeva za zaštitu osnovnih prava i sloboda čovjeka (koja su, kako međunarodnim, tako i unutarnjim pravnim aktima zagarantovana svim građanima bez diskriminacije u odnosu na rasu, spol, vjersku, političku ili drugu pripadnost, krivični progon i dr.).

Institut nezakonitih dokaza uvijek se i u svakoj državi razvija kroz sudsku praksu. Minimalni standardi korištenja, odnosno zabrane korištenja nezakonitih dokaza postavljeni su na supranacionalnom nivou kroz međunarodne dokumente o ljudskim pravima, odnosno na ustavnom i zakonodavnom nivou u unutarnjim pravnim poredcima svake države. Rješavanje pitanja nezakonitih dokaza u temeljima je ostvarenja svrhe djelovanja krivičnog pravosuđa kao primjenjivača krivičnog procesnog prava. ${ }^{1}$

Zakon o krivičnom postupku Bosne i Hercegovine, ${ }^{2}$ kao i zakoni o krivičnim postupcima Federacije Bosne i Hercegovine, ${ }^{3}$ Republike Srpske ${ }^{4}$ i Brčko distrikta ${ }^{5}$ (dalje u tekstu: ZKP BiH, ZKP FBiH, ZKP RS, ZKP BD BiH) propisuju apsolutnu zabranu upotrebe nezakonitih dokaza te ukidanje presude kao posljedicu upotrebe dokaza u krivičnom postupku na kojima se nije mogla utemeljiti sudska presuda.

\footnotetext{
${ }^{1}$ CARIĆ M., Zabrana utemeljenja sudskih odluka na nezakonitim dokazima, Hrvatski ljetopis za kazneno pravo i praksu. vol. 13, br. 2, Zagreb, 2006., str. 993.

${ }^{2}$ Zakon o krivičnom postupku Bosne i Hercegovine, Službeni glasnik BiH, broj 3/03, 32/03, 36/03, 26/04, 63/04, 13/05, 48/05, 46/06, 76/06, 29/07, 32/07, 53/07, 76/07, 15/08, 58/08, 12/09, 16/09, 93/09, 72/13. (dalje u tekstu: ZKP BiH). Ukoliko pored odredbe nije naveden naziv zakona, misli se na ZKP BiH.

${ }^{3}$ Zakon o krivičnom postupku Federacije Bosne i Hercegovine, Službene novine FBiH, broj 35/03, 37/03, 56/03, 78/04, 28/05, 55/06, 22/07, 53/07, 9/09, 12/10, 8/13, 59/14. (dalje u tekstu: ZKP FBiH).

${ }^{4}$ Zakon o krivičnom postupku Republike Srpske, Službeni glasnik RS, broj 53/12 i 91/17. (dalje u tekstu: ZKP RS).

${ }^{5}$ Zakon o krivičnom postupku Brčko distrikta Bosne i Hercegovine - prečišćeni tekst, Službeni glasnik BD BiH, broj 33/13, 27/14. (dalje u tekstu: ZKP BD BiH).
} 


\section{Nezakoniti dokazi}

\subsection{Pojam i vrste nezakonitih dokaza}

Zakonsko uređenje krivičnog postupka ima za cilj normiranje pravila po kojima postupaju sudovi, stranke i drugi učesnici u krivičnom postupku, a sve kako bi se u skladu sa osnovnim načelima postupka utvrdilo da li je neka osoba počinila krivično djelo te ako jeste da mu se u zakonom propisanom postupku izrekne odgovarajuća krivično-pravna sankcija.

Zakon o krivičnom postupku $\mathrm{BiH}$ (a čije odredbe su identične i u entitetskim zakonima te zakonu $\mathrm{BD} \mathrm{BiH}$ ) ne određuje posebna formalna dokazna pravila, već propisuje da ocjena postojanja ili nepostojanja određenih činjenica nije vezana niti ograničena posebnim formalnim dokaznim pravilima. To svakako ne znači da slobodna ocjena dokaza dozvoljava proizvoljnost postupajućem sudu u ocjeni dokaza jer takva ocjena mora biti utemeljena na logičnosti, pravilima različitih struka te procesnim pravilima o ocjeni dokaza na kojima se zasniva presuda.

Iako zakonodavac ne određuje šta može biti dokaz u određenom krivičnom predmetu kroz institut nezakonitih dokaza, propisujući dokaze na kojima sud ne može zasnovati sudsku odluku, odnosno slučajeve u kojima bi se radilo o nezakonitom dokazu, može se zaključiti da ograničenja u pogledu izvođenja dokaza ipak postoje.

Primjena nedozvoljenih dokaznih sredstava vezana je posebno za napredak cjelokupne nauke, a posebno tehničkih disciplina. Ona sa sobom nosi i ogromne potencijalne opasnosti i prijeti da ugrozi elementarna čovjekova prava. Naime, primjenom nekih novih metoda i sredstava, stvaraju se uslovi za prodor i u najskrovitije dijelove ljudske intime i otvaraju neka od fundamentalnih pitanja dopuštenosti i granica primjene pojedinih dokaznih sredstava. Međutim, savremeni krivični proces ne može odgovoriti svojoj društvenoj ulozi, niti zadacima koji se pred njega postavljaju, bez snažnog oslonca na druge nauke. Dakle, smisao ispravnog stava ne može se sastojati u odbacivanju ili potpunom zanemarivanju novih metoda i sredstava, već u svođenju njihove primjene u odgovarajuće pravne i etičke okvire. ${ }^{6}$

Stoga se može s pravom reći da je nezakonit dokaz onaj dokaz koji se zbog povrede procesne forme, koja istovremeno predstavlja povredu osnovnih ljudskih prava, ne smije koristiti za donošenje presude u krivičnom postupku. ${ }^{7}$

\footnotetext{
${ }^{6}$ SIMOVIĆ, M. Krivično procesno pravo Uvod i opšti dio, Bihać, Pravni fakultet Univerziteta u Bihaću, 2009. str. 322-323.

${ }^{7}$ GRUBAČ, M. Krivično procesno pravo, Uvod i procesni subjekti, Beograd, 2004., str. 279.
} 


\subsection{Zakonsko uređenje nezakonitih dokaza i pravne posljedice povrede zabrane upotrebe nezakonitih dokaza}

Prije upuštanja u analizu odredbe člana 10. ZKP BiH (kako je već uvodno rečeno identične odredbe sadrže član 10. ZKP RS, ZKP BD BiH i član 11. ZKP FBiH) prema zakonskom uređenju nezakonitih dokaza kroz institut "Zakonitost dokaza", iste možemo svrstati u tri osnovne vrste:

a) dokazi pribavljeni povredama ljudskih prava $\mathrm{i}$ sloboda propisanih Ustavom $\mathrm{i}$ međunarodnim ugovorima koje je Bosna i Hercegovina ratifikovala,

b) dokazi koji su pribavljeni bitnim povredama odredaba Zakona o krivičnom postupku,

c) dokazi za koje se saznalo iz nezakonitih dokaza (tzv. "doktrina plodova otrovne voćke").

Članom 10. stav (1) ZKP BiH zabranjuje se od osumnjičenog, optuženog ili bilo kojeg drugog lica koje učestvuje u postupku iznuđivati priznanje ili kakvu drugu izjavu. Ova norma uvedena je u odredbe zakona kako bi se osigurala od samovolje u postupanju istražnih organa ustavna prava i slobode građana, a koja svoj pravni izvor pronalazi i u normama međunarodnog prava o pravima čovjeka koja predviđaju da niko ne može biti podvrgnut mučenju ili okrutnom, nehumanom ili ponižavajućem kažnjavanju ili postupanju. Član 1. Konvencije protiv torture i drugih surovih, neljudskih ili ponižavajućih kazni i postupaka propisuje da je tortura svaki akt kojim se jednom licu namjerno nanosi bol ili teška tjelesna ili duševna patnja - da bi se od tog lica ili nekog drugog lica dobilo obavještenje ili priznanje. Pitanje da li je postupak nehuman, mora da bude procijenjeno prema okolnostima predmeta i preovlađujućim stanovištima. Neljudski tretman mora imati minimalan stepen jačine ukoliko se svrstava u okvir člana 3. EKLJP. Procjena ovog minimuma je, po prirodi stvari, relativna. ${ }^{8}$ Ona zavisi od svih okolnosti predmeta, kao što su priroda i sadržaj postupka, njegovo trajanje i njegove fizičke i mentalne posljedice, a u nekim slučajevima i spol, starosna dob i zdravstveno stanje žrtve. ${ }^{9}$

Prema odredbi stava (2) člana 10. ZKP BiH, "Sud ne može zasnovati svoju odluku na dokazima pribavljenim povredama ljudskih prava i sloboda propisanih Ustavom i

\footnotetext{
${ }^{8}$ SIMOVIĆ, M., op.cit., str. 323.

${ }^{9}$ Odluka Ustavnog suda BiH, br. AP-173/02 od 15.06.2004., Službeni glasnik BiH, br 40/04.
} 
međunarodnim ugovorima koje je Bosna i Hercegovina ratifikovala, niti na dokazima koji su pribavljeni bitnim povredama ovog zakona."

Dokazi pribavljeni povredama ljudskih prava i sloboda propisanih Ustavom i međunarodnim ugovorima koje je Bosna i Hercegovina ratifikovala bi, naprimjer, bili dokazi koji su pribavljeni povredom prava na odbranu (član 6. stav 3. EKLJP i član 14. stav 3. MPGPP), povredom prava na dostojanstvo, ugled i čast (član 3. EKLJP i član 7. MPGPP) ili povredom prava na nepovredivost ličnog i porodičnog života (član 8. EKLJP i član 17. $M P G P P)$.

U pogledu dokaza koji su pribavljeni bitnim povredama procesnog zakona kao primjeri se mogu navesti dokazi pribavljeni pretresanjem stana, prostorija i lica ako je pretresanje izvršeno bez sudske naredbe ili bez prisustva lica koja moraju biti prisutna pretresanju (član 53. stav 1. i član 60. Zakona) ili dokazi pribavljeni privremenim oduzimanjem pisama, telegrama, i drugih pošiljki, ako su te mjere preduzete bez sudske naredbe (član 67. stavovi 3. do 5.) ili bez prisustva dva svjedoka (član 67. stav (9) Zakona); dokazi pribavljeni primjenom posebnih istražnih radnji iz člana 116., ako su te radnje preduzete bez naredbe sudije za prethodni postupak (član 121.).

Stavom (3) istog člana propisano je da sud ne može zasnivati svoju odluku na dokazima koji su dobijeni na osnovu nezakonitih dokaza, ${ }^{10}$ odnosno za koje se saznalo iz nezakonitih dokaza (tzv. plodovi otrovne voćke).

Iako zakon ne predviđa da se dokazi pribavljeni na zakonom zabranjen način moraju izdvojiti iz spisa, smisao zabrane upotrebe ovakvih dokaza ogleda se upravo u njihovom izdvajanju iz spisa jer nezakonit dokaz inficira spis predmeta i postoji obaveza njegovog izdvajanja. U tom smislu, rješenje o izdvajanju pravno nevaljanog dokaza donosi sudija za prethodno saslušanje, i to kako u postupku odlučivanja po optužnici (član 228. Zakona), tako i prilikom odlučivanja o prethodnim prigovorima (član 233. stav (1) tačka d) Zakona). ${ }^{11}$

Zabrana upotrebe nezakonitih dokaza vrijedi u cijelom krivičnom postupku, od njegovog započinjanja do završetka i odnosi se na sve predmete (glavne i sporedne), odnosno

\footnotetext{
${ }^{10}$ Iste odredbe sadrže član 10. ZKP RS, član 11. ZKP FBiH i član 10. ZKP BD BiH.

${ }^{11}$ SIJERČIĆ - ČOLIĆ, H. et.al., Komentar zakona o krivičnom/kaznenom postupku u BiH, Vijeće Evrope/Evropska komisija, Sarajevo, 2005., str. 65.
} 
na sve oblike postupka. ${ }^{12}$ Spoznajna vrijednost ovakvih dokaza ne može "konvalidirati" nezakonitost. ${ }^{13}$

Pošto su dokazi pribavljeni na zakonom zabranjen način ili kršenjem osnovnih ljudskih prava i sloboda, te bitnim povredama zakona pravno nevaljani, to se i sudska odluka koja se temelji na takvim dokazima smatra nevaljanom i ukida se. Zajednički nazivnik nezakonitim dokazima u svim državama jeste njihovo isključenje iz osnovice za donošenje presude prema pravilu koje se u Njemačkoj naziva dokazna zabrana, odnosno određenije zabrana ocjene dokaza (Beweisverwertungsverbot), a u angloameričkim pravnim porecima ekskluzijsko pravilo (exclusionary rule). ${ }^{14}$

\subsection{Apsolutni i relativni sistem izdvajanja nezakonitih dokaza}

U sistemu nezakonitih dokaza značajnu ulogu ima svrha koja se izdvajanjem dokaza nastoji postići. Procjena je li određeni dokaz potrebno izdvojiti može se utvrđivati na dva osnovna načina. Može biti pravno propisano da je zbog neke povrede pribavljeni dokaz potrebno automatski izdvojiti bez uvažavanja okolnosti nastanka povrede ili njezina utjecaja na druge vrijednosti u krivičnom postupku, što se najčešće naziva apsolutni (automatski ili mehanički) način izdvajanja jer ista povreda uvijek dovodi do nedopustivosti uporabe dokaza neovisno, na primjer, je li riječ o najtežem krivičnom djelu i jesu li službenici koji su prikupljali dokaze bili u razboritom uvjerenju da poštuju zakon.

Nasuprot tome, drugi oblik kojim se dokaz ne izdvaja obavezno nakon utvrđivanja određene povrede, već se uvažavaju i ostale okolnosti poput težine krivičnog djela, namjere policijskog službenika i slično, najčešće se naziva relativno (razmjerno ili diskrecijsko) izdvajanje jer ista povreda ne dovodi uvijek do izdvajanja dokaza, već ishod ovisi o raznim uključenim okolnostima. ${ }^{15}$

Uz način izdvajanja, za sistem nezakonitih dokaza bitan je element obim primjene, odnosno opseg povrede zbog kojih se izdvajanje dokaza može primijeniti. Od mnogobrojnih krivičnoprocesnih odredaba o prikupljanju dokaza nijedna ne određuje izdvajanje dokaza za

\footnotetext{
12 SIMOVIĆ, M., op.cit, str. 324.

${ }^{13}$ PAVIŠIĆ, B., Kazneno postupovno pravo, Pravni fakultet, Rijeka, 2008., str. 33.

${ }^{14}$ BOJANIĆ, I., ĐURĐEVIĆ, Z. Dopuštenost upotrebe dokaza pribavljenih kršenjem temeljnih ljudskih prava, Hrvatski ljetopis za kazneno pravo i praksu, broj 2, Zagreb, 2008., str. 974.

${ }^{15}$ KARAS, Ž., JUKIĆ, M., Promjene u sustavu nezakonitih dokaza s osvrtom na kretanja u poredbenom pravu, Hrvatski ljetopis za kazneno pravo i praksu. vol. 16, broj 2, Zagreb, 2009., str. 605-606.
} 
sve propuste, već se može propisati samo za pojedine nezakonitosti ovisno o njihovoj važnosti. U obim izdvajanja spada i odnos prema proizašlim dokazima za koje se saznalo iz nezakonitog dokaza (doktrina plodova otrovne voćke). Kombinacijom tih osnovnih elemenata pojedini se sustav nezakonitih dokaza može prilagođivati ostvarivanju svrhe koju definira. ${ }^{16}$

\subsection{Doktrina „plodova otrovne voćke“}

Doktrina "plodova otrovne voćke" općeprihvaćena je pravnoteorijska konstrukcija jedne od kategorija nezakonitih dokaza, koja predstavlja dokaze za koje se saznalo iz nezakonitih dokaza. Riječ je o izvedenom dokazu koji je per se zakonit, ali saznanje o tom dokazu potječe od nekog drugog dokaza, pribavljenog na nezakonit način. ${ }^{17}$ Time je dosljedno provedeno isključivanje nezakonitih dokaza iz činjenične građe na temelju koje sud donosi odluku, kako samog nezakonitog dokaza, tako i izvedenog dokaza koji se smatra njegovim "saznajnim sadržajem". ${ }^{18}$ Svoju definiciju ove doktrine dao je i Vrhovni sud Republike Hrvatske u obrazloženju svoje odluke. ${ }^{19}$

Očito je da se dokaz za koji su tijela krivičnog postupka saznala iz nezakonitog dokaza mora u cijelosti ili barem u pretežitom dijelu svog sadržaja odnositi na iste pravno relevantne činjenice, kao i sadržaj izvornog nezakonitog dokaza. No, kako takvih “izvedenih”, derivativnih dokaza može biti više, postavlja se pitanje stupnja te veze da bi se taj derivativni dokaz, do kojega se došlo na podlozi prvog, mogao smatrati njegovom posljedicom. ${ }^{20}$ Naziv "plodovi otrovne voćke" pripada anglo-američkom pravu. ${ }^{21}$.

Kroz praksu američkog Vrhovnog suda nastala je slikovito imenovana doktrina "plodova otrovne voćke" (the fruit of the poisonous tree doctrine ili Derivative Evidence Doctrine). Navedena doktrina predstavlja najširi domet ekskluzijskog pravila u SAD-u: riječ je o širenju ekskluzije dokaza, ne samo na one dokaze koji su dobiveni na nezakonit način, već i

\footnotetext{
${ }^{16}$ Ibid., str. 606.

${ }^{17}$ CARIĆ, M., Izdvajanje nezakonitih dokaza iz spisa predmeta - ključni trenutak kaznenog postupka. Aktualna pitanja kaznenog zakonodavstva, Inženjerski biro, Zagreb, 2004., str. 298.

${ }^{18}$ loc.cit.

${ }^{19}$ Prema doktrini tzv. plodova otrovne voćke, nezakoniti su i drugi dokazi za koje se saznalo iz nezakonitih dokaza. Za primjenu te doktrine potrebno je postojanje izvorno nezakonitog dokaza (otrovne voćke) iza kojeg potom slijedi nov dokaz koji bi inače bio zakonit, ali s obzirom na to da je taj novi dokaz plod nezakonitog dokaza i taj novi dokaz je nezakonit. Drugim riječima, ako je izvorni dokaz nezakonit, tada je i dokaz proizašao iz njega također nezakonit (kao što je zatrovan i plod otrovne voćke). Presuda Vrhovnog suda RH, I Kž 926/2008-3.

${ }^{20}$ KRAPAC, D. Kazneno procesno pravo, Prva knjiga: Institucije, IV. izmijenjeno i dopunjeno izdanje, Zagreb, 2010., Narodne novine, str. 330.

${ }^{21}$ Prvi put naziv se koristi u predmetu Nardone vs. U. S. iz 1939. godine te se pripisuje sucu Federalnog Vrhovnog suda SAD Frankfurteru.
} 
na dokaze koji uzročno-posljedično proizlaze iz tih nezakonitih dokaza. Svrha takve proširene ekskluzije jest onemogućavanje upotrebe dokaza dobivenih povredom Ustava u krivičnom postupku. $^{22}$

Vrhovni sud SAD-a već je 1914. u predmetu Weeks v. United States ${ }^{23}$ usvojio ekskluzijsko pravilo, međutim ostalo je otvoreno pitanje odnosi li se ono samo na direktno nezakonite dokaze ili se odnosi i na dokaze koji su indirektno proizašli iz nezakonitih. Odgovor na to pitanje Vrhovni je sud dao već 1920. u predmetu Silverthorne Lumber Co. v. United States $^{24}$, gdje je prvi put prihvaćena doktrina "plodova otrovne voćke", iako nije još bila nazvana tim imenom. Vlada je tvrdila da Ustav SAD-a zabranjuje nezakonito pribavljanje dokaza, ali ne i svaku prednost koju bi vlada mogla ostvariti nad optuženim pomoću informacija dobivenih kao rezultat nezakonitog postupanja. Sud je objasnio da dokazi dobiveni na taj način, ne samo da se ne mogu koristiti pred Sudom, već se ne mogu uopće koristiti.

Ova doktrina još se 19 godina razvijala bez imena, da bi 1939. u presudi Nardone v. United States ${ }^{25}$ bila nazvana “doktrinom plodova otrovne voćke.” Ipak, najznamenitiji primjer doktrine "plodova otrovne voćke" jest presuda Wong Sun v. United States. ${ }^{26}$ U tom predmetu radilo se o tome da je policija samo na temelju obavijesti da Toy prodaje drogu, a bez razumne sumnje i naloga, upala u njegovu praonicu rublja tražeći drogu. Iako droga nije pronađena, Toy je priznao svoju upletenost u preprodaju droge te optužio i Yeea. Policija je kod Yeea zaista i našla drogu, a on je krivnju prebacio nazad na Toya te na Wong Suna koji je nedugo zatim uhićen. Wong Sun i Yee nakon nekoliko dana su pušteni te su samoinicijativno otišli na policiju i priznali upletenost u preprodaju droge. Tužiteljstvo je na suđenju Toyu i Wong Sunu zbog preprodaje i prikrivanja droge predložilo kao dokaze Toyevu izjavu nakon uhićenja, drogu nađenu kod Yeea te priznanja Yeea i Wong Suna.

Nama je zanimljivo kako je Vrhovni sud ocjenjivao predložene dokaze. Izvor svih dokaza je Toyevo uhićenje, koje je sud ocijenio nezakonitim. Kako svi daljnji dokazi proizlaze iz Toyeva uhićenja, pitanje je kako ocijeniti dokaze koji su pribavljeni na temelju tog dokaza. Na suđenju Toyu sud je utvrdio da je prvotno nezakonito uhićenje onaj izvor koji je "otrovao"

\footnotetext{
${ }^{22}$ Suština ove teorije se svodi na to da se na protivpravno pribavljenim dokazima, kao ni na pravno perfektno pribavljenim dokazima do kojih se došlo posredno preko nekih drugih protivpravno probavljenih dokaza, ne može zasnivati sudska odluka. Radulović, J., Sinteza procesnih stilova adversijalnog i mešovitog krivičnog procesnog prava na primeru Međunarodnog krivičnog tribunala za bivšu Jugoslaviju. Pravni zapisi, God. V, br. 1, 2014., str. 259-289., str. 270

23232 U.S. 383 (1914.).

24251 U.S. 385 (1920.).

25308 U.S. 338 (1939.).

26371 U.S. 471 (1963.).
} 
sve dokaze koji proistječu iz njega. Prema tome, nezakonita je Toyeva izjava kojom je inkriminirao Yeea, ali i droga koja je nađena kod Yeea na temelju Toyeve izjave. Iako je droga vrlo udaljen dokaz u dokaznom lancu, sud je ocijenio da je ona u dovoljno velikoj neposrednoj vezi s prvotnim nezakonitim uhićenjem, pa je potrebno taj dokaz izdvojiti. Međutim, na suđenju Wong Sunu Vrhovni sud je odlučio drukčije. Droga zaplijenjena kod Yeea u tom se primjeru može upotrijebiti kao dokaz jer nije dobivena kršenjem njegova prava na privatnost, već kršenjem prava treće osobe (Toya). Dakle, sama zapljena droge kod Yeea nije bila nezakonita per se, već je bila nezakonita u povezanosti s nezakonitim uhićenjem Toya, koje je dovelo do njegove izjave i pronalaska droge. Međutim, sud je pri ocjeni Wong Sunovog priznanja koje je dano nekoliko dana nakon puštanja iz zatvora zaključio da ono zbog vremenske udaljenosti nije povezano s prvotnim nezakonitim uhićenjem te je stoga dopustivo kao dokaz. Ovdje imamo zanimljivu situaciju da je isti dokaz (droga otkrivena kod Yeea) na suđenju Toyu izdvojen, a na suđenju Wong Sunu dopušten! Do takvog razlikovanja došlo je zbog različite povezanosti dvojice optuženih s tim dokazom. Tu se već otvara pitanje iznimaka od doktrine "plodova otrovne voćke".

Ako bismo ovu teoriju tumačili ekstenzivno, u dokaznom lancu jedan nezakoniti dokaz automatski bi "otrovao" sve ostale dokaze, bez obzira na različite načine i okolnosti pod kojima su takvi dokazi pribavljeni. Često se u dokaznom lancu pojavljuju dokazi koje policija otkrije na zakonit način, ali ih nikad ne bi otkrila da nije bilo prvotnog nezakonitog dokaza. Postavlja se pitanje treba li izdvojiti sve takve dokaze ili neki događaji i radnje prekidaju uzročnu vezu između nezakonitih dokaza i dokaza koji proizlaze iz njih - "plodova otrovne voćke". ${ }^{27}$

Međutim, kako bi se suzila dosljedna primjena pravila o apsolutnom izdvajanju nezakonitih dokaza iz činjenične građe, američka sudska praksa je vremenom, putem iznimaka od doktrine "plodova otrovne voćke", usvojila i izgradila stav u kojim je situacijama korištenje plodova otrovne voćke u sudskom postupku dopušteno.

\subsection{Izuzeci od „doktrine plodova otrovne voćke“6}

Američka sudska praksa stvorila je nekoliko iznimaka od doktrine "plodova otrovne voćke” zbog kojih se neki dokazi koji proizlaze iz prvotnog nezakonitog dokaza ne izdvajaju. U nastavku iznosimo pregled takvih iznimaka.

\footnotetext{
${ }^{27}$ LAFAVE, W. R. et.al., Criminal procedure, 3rd edition., West Group, St. Paul, 2000., str. 503-504.
} 
2.5.1. Doktrina "očišćene mrlje” (purged taint doctrine) glasi: "ako dovoljno dodatnih čimbenika posreduje između izvorne nezakonitosti i konačnog otkrića dokaza, niti zastrašivanje niti pravičnost postupka ne mogu opravdati primjenu ekskluzijskog pravila. Prema tome, dokazi mogu biti prihvatljivi unatoč činjenici da ne bi bili otkriveni bez prvotne nezakonitosti." 28

Najbolji primjer za ovu iznimku od teorije "plodova otrovne voćke" upravo je citirani predmet Wong Sun. Sud u tom predmetu zaključuje da "nije svaki dokaz plod otrovne voćke samo zato što ne bi bio otkriven bez nezakonitog postupanja policije. Važnije je pitanje jesu li takvi dokazi proizašli iz iskorištavanja prvotne nezakonitosti ili sredstvima koja su dovoljno udaljena da bi očistila mrlju prvotne nezakonitosti”. Znači, ako su prvobitni nezakoniti dokaz i dokaz dobiven na temelju tog dokaza vremenski ili na neki drugi način toliko udaljeni da više ne možemo govoriti o aktivnom iskorištavanju prvotne nezakonitosti, uzročna je veza između njih prekinuta i mrlja prvotne nezakonitosti je "očišćena” te je izvedeni dokaz, tj. "plod otrovne voćke", dopušten. Dakle, važnost predmeta Wong Sun je u tome što on predstavlja i primjenu doktrine "plodova otrovne voćke" pri izdvajanju dokaza dobivenih aktivnim iskorištavanjem primarne nezakonitosti, ali i primjenu iznimke "očišćene mrlje" koja dopušta upotrebu drugih dokaza koji ne bi bili otkriveni da nije bilo takve nezakonitosti. Upravo zbog te iznimke Vrhovni sud je napravio razliku u ocjeni dokaza u suđenjima Toyu i Wong Sunu. Toyeve izjave Sud je uzeo kao neposrednu posljedicu nezakonitog uhićenja jer su dane odmah nakon uhićenja i upada policije. Kod Wong Suna situacija je bila drukčija jer je između njegova uhićenja i priznanja proteklo nekoliko dana. Iako do Wong Sunova priznanja ne bi došlo da nije bilo nezakonitog uhićenja Toya, ocijenjeno je da je priznanje u njegovu slučaju rezultat slobodne volje koja prekida uzročnu vezu nezakonitosti između dvaju dokaza. Na temelju izrečenog sud je zaključio da je "povezanost između uhićenja i priznanja tako slaba da je prvotna nezakonitost očišćena."

2.5.2. Doktrina “neovisnog izvora”. Vrhovni sud već je 1920. u spomenutoj presudi Silverthorne Lumber Company v. United States usvojio iznimku "neovisnog izvora" - Vrhovni sud u toj presudi tvrdi: "Ako je saznanje o nezakonito pribavljenim činjenicama stečeno iz neovisnog izvora, one se mogu dokazivati kao i sve druge, ali saznanje stečeno vlastitom pogreškom Vlade ne može se koristiti na predloženi način.” Problem s iznimkom "neovisnog izvora" javlja se kad su nezakoniti i zakoniti izvor dokaza tako usko povezani da je upitno je li zakoniti izvor neovisan. Bit te iznimke su slučajevi kad policija do "ploda otrovne voćke" ne

\footnotetext{
${ }^{28}$ EMANUEL, S. L., Criminal Evidence, Aspen Publishers, Aspen, 2007., str. 293.
} 
dođe na temelju iskorištavanja prvotne nezakonitosti već na temelju nekog drugog neovisnog izvora. Riječ je o situaciji kad bi sud morao neki dokaz izdvojiti jer je proizašao iz nezakonitog dokaza, ali policija uspije do takvog dokaza doći na neki drugi način koji je zakonit i neovisan. Policija ovdje mora dokazati da je do dokaza došla na "čist" način, što znači neovisno o prvotnom nezakonitom dokazu. ${ }^{29}$

Opravdanje te iznimke opisano je u predmetu Nix $v$. Williams ${ }^{30}$ gdje sud objašnjava da se policiju, tj. tužitelja ne smije postaviti u slabiji položaj od onog u kojem bi bili da nisu došli do nezakonito dobivenog dokaza. Isto tako, optuženog se ne smije samo zbog postojanja istovremeno nezakonito dobivenog dokaza staviti u bolji položaj. To bi značilo da kad bi policija jednom pronašla neki dokaz na nezakonit način, ne bi ga mogla više sanirati ni na koji način, čak ni kad bi neki drugi policajac istovremeno došao do istog dokaza na zakonit način. Takva interpretacija bila bi u suprotnosti sa samim smislom ove doktrine. ${ }^{31}$

2.5.3. Doktrina "neizbježnog otkrića" jeste najinovativnija iznimka doktrine "plodova otrovne voćke'. Ova iznimka se zasniva na tvrdnjama u pojedinim slučajevima da bi vlasti nedvojbeno pronašle 'onečišćen' dokaz na zakonit način. Kroz ovu iznimku tužitelju je dana mogućnost da sanira izvorno 'onečišćenje' koje se pripisuje dokazu te da ga učini prihvatljivim u dokaznom postupku pred sudom." 32

Reprezentativni primjer te iznimke je spomenuti slučaj Nix $v$. Williams. Na suđenju Williamsu zbog ubojstva postavilo se pitanje može li se kao dokaz koristiti leš koji je policija otkrila na temelju izjave optuženog. Ta je izjava, naime, bila izdvojena jer je do nje policija došla pomoću trika. Obrana je zbog toga zahtijevala da se kao dokaz izdvoji i truplo, dok je optužba ponudila dokaze da bi truplo našli i neovisno o izjavi optuženoga. Kad se tužitelj poziva na iznimku "neizbježnog otkrića", on mora standardom nadmoćnog dokaza ${ }^{33}$ dokazati da bi do nekog dokaza nužno došao i zakonitim sredstvima.

Ova iznimka je naizgled slična iznimci "neovisnog izvora", međutim između njih postoji i velika razlika. Ta je razlika u tome što je kod iznimke "neovisnog izvora" dokaz koji

\footnotetext{
${ }^{29}$ OBRADOVIĆ, B., ŽUPAN, I. „Plodovi otrovne voćke“ u hrvatskom i poredbenom pravu, 2011., broj 1., Zagreb, Hrvatski ljetopis za kazneno pravo i praksu, str. 118.

30467 U.S. 431 (1984.).

${ }^{31}$ LAFAVE, W.R., et al., op.cit., str. 506-507.

${ }^{32}$ BAIN, J. M., KELLY, M. K. Fruit of the poisonous tree: recent developments as viewed through its exceptions, Vol. 31, broj 3, University of Miami Law Review, 1977., str. 625.

33 "Nadmoćni dokaz kao dokazni standard u građanskim predmetima je dokaz koji ima veću težinu i uvjerljivost od dokaza koji je ponuđen kao njegova suprotnost, tj. dokaz koji u cjelini pokazuje da je vjerojatnije postojanje činjenice koja se njime dokazuje nego nepostojanje takve činjenice.” Black, H. C., Black's Law Dictionary. St. Paul, Minnesota, 1990., West Publishing Co.
} 
je pronađen iskorištavanjem nezakonitosti pronađen i zakonitim putem, dok kod iznimke "neizbježnog otkrića”, dokaz pronađen iskorištavanjem nezakonitosti nije pronađen zakonitim putem. Još jedna sličnost tih dviju iznimaka jest logika njihova opravdavanja. I iznimka "neizbježnog otkrića" može se opravdati na sličan način kao i iznimka "neovisnog izvora". Optuženi bi, da ne postoji iznimka "neizbježnog otkrića", bio u boljem položaju da je zbog trika rekao za truplo nego da nije rekao za nj. Truplo bi ionako bilo pronađeno pa je nepošteno favorizirati optuženoga jer policija slučajno još nije došla do dokaza do kojeg bi došla i bez uporabe nezakonite metode (trika).

Još jedna, možda i najkontroverznija iznimka od doktrine "plodova otrovne voćke”,

2.5.4. Doktrina “dobre vjere” uspostavljena je u predmetu Vrhovnog suda SAD U.S. v. Leon. ${ }^{34}$ Policija je pribavila neke dokaze prilikom pretresa stana na temelju sudskog naloga. Međutim, policija nije zadovoljila kriterij razumne sumnje kad je zahtijevala nalog od suda, a to je jedan od nužnih uvjeta za njegovo izdavanje, pa je prema tome nalog bio nezakonit. Postavilo se pitanje treba li izdvojiti dokaze otkrivene prilikom takvog pretresa stana. Sud je ocijenio da se na suđenju mogu upotrijebiti dokazi koje je policija otkrila u razumnoj dobroj vjeri. Obrazložio je svoju odluku argumentima da je ekskluzijsko pravilo prije svega preventivno sredstvo protiv postupanja policije, a ne sudske vlasti, da ne postoje dokazi da su sudije naklonjene nepoštovanju pravnih propisa te da se ne može očekivati od policije da provjerava odluku suda ili se dvoumi oko nje. Tom odlukom Vrhovni sud je postavio vrlo široku iznimku od doktrine "plodova otrovne voćke" te zadao velik udarac ekskluzijskom pravilu jer je napravio razlikovanje između nezakonitog postupanja suda i nezakonitog postupanja policije. Vrhovni sud je ovom iznimkom narušio pravičnost jer nije sankcionirao nezakonito postupanje suda, koji se upravo mora brinuti o pravnoj sigurnosti i ima ovlasti kazniti one koji se ne drže pravnih pravila. ${ }^{35}$

Ostale iznimke tiču se činjenice da svjedočenja nisu tipična iznimka doktrine "plodova otrovne voćke", ali čine važno područje u kojem su sudovi pokušali zaobići ovu doktrinu. Izjava svjedoka smatra se "otrovnom" kad je njegov identitet otkriven kao rezultat početne nezakonitosti. U nekim slučajevima nakon 1970. izdvojena su svjedočenja na tom temelju. $\mathrm{Na}$ primjer, u predmetima United States v. Barragan-Martinez ${ }^{36} i$ United States v. Guana-

\footnotetext{
${ }^{34} 468$ U.S. 897 (1984.).

${ }^{35}$ OBRADOVIĆ, B., ŽUPAN, I., op.cit. str. 120.

36504 F.2d 1155 (9th Cir. 1974.).
} 
Sanchez ${ }^{37}$ optužene je zaustavila policija prilikom upravljanja motornim vozilima. Putnici u vozilima morali su svjedočiti protiv optuženih. U oba slučaja utvrđeno je da policija nije imala valjan razlog da zaustavi vozila pa su zato izjave putnika koje su inkriminirale zabranjene kao "plodovi" takve nezakonitosti. ${ }^{38}$

U novijoj presudi U.S. v. Patane ${ }^{39}$ gospodin Patane uhićen je jer je zvao svoju bivšu djevojku unatoč sudskoj zabrani. Prilikom uhićenja policija mu je čitala njegova prava (što se u američkoj teoriji naziva Miranda upozorenja), no on ih je prekinuo jer je rekao da zna svoja prava i priznao im da ima pištolj u stanu. Policija je uz njegovo dopuštenje ušla u stan i našla pištolj koji on nije smio posjedovati te je na temelju toga podignuta optužnica protiv njega. Postavilo se pitanje mogu li se fizički dokazi pronađeni kao rezultat dobrovoljnog iskaza kojem nisu prethodila Miranda upozorenja koristiti na sudu. Sud je odgovorio potvrdno. U presudi tri suca ističu da su Miranda upozorenja namijenjena samo kako bi se spriječilo kršenje Ustava. Fizički dokazi pribavljeni na temelju izjava kojima nisu prethodila takva upozorenja, dok god takve izjave nisu rezultat policijske prisile, stoga su ustavno dopušteni. Druga dva suca koja su podržala takvu presudu također su smatrala da su fizički dokazi ustavno dopušteni, ali to pravdaju time da Miranda upozorenja trebaju biti usmjerena na druge ciljeve krivičnog pravosuđa. Nisu razmatrali jesu li Miranda upozorenja per se nužna po Ustavu SAD-a.

\section{Uporednopravni aspekti položaja nezakonitih dokaza}

Kad se promatra stanje u uporednom pravu, vidljivo je da se većina pravnih sistema ne koristi apsolutnim oblikom izdvajanja dokaza iz krivičnog spisa, koje bi bilo široko usmjereno na povrede u radnjama prikupljanja materijalnih dokaza. Upravo suprotno, takav je model predmet kritika zbog brojnih nedostataka i negativnih posljedica. Rijetki sistemi koji se koriste apsolutnim načinom izdvajanja pritom nemaju širok obim pravila, primjenjuju razne iznimke te ne obuhvaćaju brojne povrede koje u našem zakonskom uređenju mogu dovoditi do nezakonitosti dokaza.

Apsolutno izdvajanje dokaza proizašlih iz nezakonitog dokaza rijetkost je i u takvim sustavima, a oni koji se njime koriste prihvaćaju relativno izdvajanje za proizišle (derivirane) dokaze. Analiza potvrđuje da je pri promatranju poredbenog prava pozornost potrebno

\footnotetext{
37484 F.2d 590 (7th Cir. 1973.).

${ }^{38}$ BAIN, J. M., KELLY, M. K., op.cit. str. 629- 630.

${ }^{39} 542$ U.S. 630 (2004.).
} 
usmjeriti, ne samo na postojanje pravila, nego i na opseg izdvajanja te na međuodnos sa širinom ovlasti redarstvenih vlasti. ${ }^{40}$

Kad se promatraju kretanja u uporednom pravu, važniji pravni sistemi koji se primarno koriste relativnim izdvajanjem i užim obimom ne pokazuju težnje preuzimanja apsolutnog izdvajanja. S druge strane, sistemi koji su preuzeli apsolutno izdvajanje kao primarno pravilo potpuno su odustali od njega, npr. novozelandski ili belgijski sistem, ili se pak koriste širokim iznimkama. Čak i američki model, koji je bio uzor brojnim državama, u novije vrijeme snažno ograničava izdvajanje nezakonitih dokaza. Najčešće su primjedbe u apsolutnom modelu da empirijska istraživanja ne pokazuju da izdvajanje ima preventivni učinak; velik dio povreda ne nastaje namjerno, a pri namjernim povredama izdvajanje dokaza ne sankcionira službenike nego društvo; izdvajanje dokaza ne ide u korist osobama kojima je povrijeđeno isto pravo, ali nisu pronađeni dokazi, a počinitelj ima nezaslužene koristi jer je krivično djelo ostavilo posljedice koje ne može poništiti naknadna procesna povreda. Relativni model izdvajanja ima veće mogućnosti prilagođavanja pojedinačnim okolnostima i može ostvarivati prikladnije učinke na krivični postupak. Kao suprotnost izvornom američkom modelu, u brojnim se državama prepoznaje pristup judikature ESLJP-a s velikim utjecajem na anglosaksonske sisteme, međunarodne sudove te države koje su odbacile apsolutno izdvajanje ili teoriju o plodovima otrovne voćke. ${ }^{41}$

Tranzicijske države s drugih područja nisu uvele ekskluzijsko pravilo, neovisno o tome što su imale veće teškoće $u$ pravilnosti prikupljanja dokaza i vjerodostojnosti vlasti. Iako su posljednja usmjeravanja prema mješovitom modelu bliskija kretanjima uporednog prava i pokazuju sklonosti evropskim sistemima, ipak je teško predvidjeti daljnji razvoj i obim koji će preuzeti. $^{42}$

\subsection{Anglosaksonski sistem izdvajanja nezakonitih dokaza}

Najvažnija razlika u načinu i opsegu izdvajanja uočava se u usporedbi većine anglosaksonskih pravnih sistema (Engleska, Kanada, Australija i dr.) s američkim modelom apsolutnog izdvajanja nezakonitih dokaza. Damaška ističe da i u kontinentalnim državama

\footnotetext{
${ }^{40}$ KARAS, Ž., ŠTRK, D. Izdvajanje nezakonitih materijalnih dokaza u poredbenom kaznenom postupovnom pravu, Zbornik Pravnog fakulteta u Rijeci, broj 2, Rijeka, 2013., str. 210.

${ }^{41}$ Ibid., str. 210-211.

42 Ibid., str. 211.
} 
postoji izdvajanje dokaza, ali da je zabluda smatrati kako je riječ o istim povredama. Nije dovoljno samo promatrati koristi li se neka država izdvajanjem nego i koje povrede obuhvaća. Američko izdvajanje nezakonitih dokaza po vrlo širokom opsegu materijalnih dokaza nema sličnosti ni s jednom drugom državom. ${ }^{43}$ Kritičarima američkog pravila o izdvajanju nezakonitih dokaza ide u prilog što se jedino SAD od svih anglosaksonskih država koriste apsolutnim izdvajanjem, dok se Engleska, Kanada, Australija i Novi Zeland koriste relativnim izdvajanjem, a uz to nemaju ni širok opseg povreda na koje se izdvajanje primjenjuje. ${ }^{44}$ Američkom se sistemu preporučuje diskrecijski model, poput kanadskoga, ${ }^{45}$ ili neki od evropskih sistema koji se koriste proporcionalnošću kao što je njemački model. ${ }^{46}$ Engleska i Kanada prepoznale su korisniji pristup izdvajanja temeljem slobodne ocjene prema okolnostima slučaja, što je povoljnije nego automatsko pravilo. ${ }^{47}$

U engleskom pravu za nezakonitosti počinjene tijekom prikupljanja stvarnih dokaza koristi se načelo pouzdanosti i sudovi ih u načelu ne izdvajaju. ${ }^{48}$ Primjerice, engleski autori ističu da su dokazi koji su prikupljeni nezakonitim pretresom načelno dopustivi. ${ }^{49}$

Prema sudskoj praksi, dokazi se ne trebaju izdvajati samo stoga što je nepravilan način na koji su pribavljeni. ${ }^{50}$ Neslaganje s načinom prikupljanja dokaza ne može se koristiti kao opravdanje za izdvajanje. ${ }^{51}$ Pri izradi zakonskog uređenja (Police and Criminal Evidence Act 1984 - PACE) Kraljevsko je povjerenstvo zaključilo da nije uvjereno u potrebu uvođenja američkog pravila jer ne pokazuje povoljne rezultate. ${ }^{52}$

U engleskom se pravu uvažava činjenica da nepravilnosti u prikupljanju najčešće ne utječu na vjerodostojnost materijalnih dokaza. Na primjer, za nezakonito uzimanje uzoraka za DNK analizu u slučaju istraživanja silovanja engleski je Apelacioni sud zaključio da način prikupljanja nije utjecao na tačnost dokaza. Usmjerenost prema provjeri vjerodostojnosti

\footnotetext{
${ }^{43}$ DAMAŠKA, M., op.cit. str. 507.

44 "Finally, a comparative legal analysis demonstrates that the United States stands alone among common law countries in mandating the exclusion of relevant evidence seized in violation of individual rights." PERRIN T. An Invitation to Dialogue. Pepperdine Law Review, vol. 26, 1999., str. 792.

${ }^{45}$ ALSCHULER, A., The Exclusionary Rule and Causation, Hudson v. Michigan and Its Ancestors, Iowa Law Review, vol. 93, 2008., str. 1777; BRADLEY, C. Reconceiving the Fourth Amendment and the Exclusionary Rule. Law And Contemporary Problems, vol. 73, 2010., str. 218.

${ }^{46}$ PIZZI, W. The Need to Overrule Mapp v. Ohio,. University of Colorado Law Review, vol. 82, 2011., str. 679.

${ }^{47}$ GLASSER, L. The American Exclusionary Rule Debate: Looking To England And Canada For Guidance, George Washington International Law Review, vol. 35, 2003., str. 195.

${ }^{48}$ DELMAS-MARTY, M., SPENCER, J. R., European Criminal Procedures, Cambridge University Press, Cambridge, 2004., str. 605.

${ }^{49}$ STONE, R. Entry, Search and Seizure, London: Sweet and Maxwell, 1997., str. 29.

${ }^{50}$ KEANE, A. The Modern Law of Evidence. Oxford, Oxford University Press, 2008., str. 62, 63.

${ }^{51}$ HARFIELD, C. Covert Investigation, Oxford University Press, Oxford, 2012., str. 28.

${ }^{52}$ ZANDER, M. The Police and Criminal Evidence Act 1984., Taylor and Francis, London, 1990., str. 199-202.
} 
izričito je naglašena u poznatoj odluci Chalkley, u kojoj je Apelacioni sud utvrdio da se izdvajanje nezakonitih dokaza treba primjenjivati ako im je zbog nepravilnog načina prikupljanja promijenjena kakvoća. ${ }^{53} \mathrm{U}$ tom je slučaju bila riječ o nezakonitim snimkama za koje je utvrđeno da su nedvojbeno autentične i da imaju relevantan sadržaj te ih sud nije izdvojio. To se pravilo poštuje u engleskoj sudskoj praksi (a složio se i ESLJP odbivši zahtjev za provjerom pravičnosti suđenja u istom predmetu). ${ }^{54} \mathrm{U}$ Engleskoj se na materijalne dokaze može primjenjivati diskrecijsko izdvajanje, ali se sudovi njime nisu koristili ni u slučajevima gušenja osumnjičenika dok nije ispljunuo predmet koji je sakrio istražiteljima, ${ }^{55}$ nego se u slučaju nezakonitosti provode disciplinski ili krivični postupci prema istražiteljima. Slično tomu, u kanadskom ni u australskom sistemu provedba neosnovane pretrage ne dovodi do apsolutnog izdvajanja dokaza. ${ }^{56}$

Novozelandski je sistem važan jer je nakon približavanja američkom apsolutnom modelu 1992. godine pravilom koje prednost daje izdvajanju (prima facie rule of exclusion) u roku kraćem od desetljeća to pravilo odbacio i vratio se na klasično anglosaksonsko diskrecijsko izdvajanje. Sistem koji je korišten nije bio čisti apsolutni model, jer su materijalni dokazi prikupljeni povredom prava ipak bili dopustivi ako su opravdani razlozi upućivali na potrebu korištenja. Promjena je ostvarena 2002. godine u slučaju Shaheed, u kojem je policija privela muškarca jer je prijetio djevojčici na putu u školu te su mu nezakonito uzeli uzorak za analizu DNK ${ }^{57}$ U bazi je otkriveno da je to počinitelj otmice i silovanja djeteta koje se dogodilo godinu dana prije na putu za istu školu. Tom je odlukom desetak godina nakon uvođenja strogog pravila o izdvajanju materijalnih dokaza ono zamijenjeno ranijom diskrecijskom ocjenom dopustivosti. ${ }^{58} \mathrm{U}$ odluci su opširno prikazani sistemi izdvajanja nezakonitih dokaza u Sjedinjenim Državama, Engleskoj, Kanadi i Australiji, nakon čega je sud zaključno naglasio da se pozornim razmatranjem proteklog iskustva te uvidom u druge države pruža uvjerljiv razlog za odbacivanje automatskog izdvajanja. Sud je naglasio da automatsko izdvajanje ne podupire težnje društva koje su usmjerene na kažnjavanje počinitelja, te se može činiti da je zaštita prava nerazmjerna okolnostima povrede. Mount ocjenjuje tu promjenu kao iznimno povoljan razvoj

\footnotetext{
${ }^{53}$ Court of Appeal, United Kingdom (R. v. Chalkley and Jeffries [1998.] 2 All ER 155).

${ }^{54}$ Evropski sud za ljudska prava, Case of Chalkley v The United Kingdom, Application no. 63831/00, Judgement, 12 June 2003.

55 TAPPER, C. Cross and Tapper on Evidence, Oxford University Press, Oxforf, 2007.,str. 309.

${ }^{56}$ ROACH, K., FRIEDLAND, M. L. Borderline Justice: Policing in the Two Niagaras, American Journal of Criminal Law, vol. 23, 1996., str. 341.

57 R v Shaheed [2002.] 2 NZLR 377., dostupno na: www.lawreports.nz/r-v-shaheed-2002-2-nzlr-377/

${ }^{58}$ MAHONEY, R., Evidence, New Zealand Law Review, 2004., str. 170.
} 
prava, koji pridonosi jasnoći i određenosti te da je postignuta bolja ravnoteža između zaštite temeljenih prava i zaštite težnja društva. ${ }^{59}$

Nepovoljne su posljedice bile već prije primijećene u novozelandskom pravu, tako da su u praksi i prije 2002. godine suci pokušavali izbjegavati izdvajanje dokaza pri težim krivičnim djelima. Potporu za odbijanje američkog sistema novozelandski su teoretičari pronašli i u odlukama ESLJP-a naglašavajući dispozitiv iz slučaja Khan, gdje je ostvarena povreda, ali nije bilo potrebno izdvajati materijalne dokaze, u skladu s odlukom Schenk. Tamošnji pravnici ističu da je izdvajanje stvarnih dokaza rijetko u Francuskoj, Njemačkoj i Italiji te da nijedna država - osim, možda, Španjolske - nije prihvatila ništa slično apsolutnom pravilu izdvajanja pri pretresu i oduzimanju. ${ }^{60}$

\subsection{Sužavanje apsolutnog izdvajanja u SAD-u}

U američkom krivičnom postupku brojna su pravila nastala pod utjecajem nastojanja za zaštitom manjina u drugačijim društvenim okolnostima, odnosno radi sudskog discipliniranja policije. ${ }^{61}$ Ključnu ulogu u nastanku pravila imao je Vrhovni sud SAD-a koji je tijekom 1960ih godina donio niz revolucionarnih pravila u brojnim pravnim pitanjima. ${ }^{62}$ Pravila su bila odgovor na bojazan od totalitarističkih sistema, institucionaliziranog rasizma, ekonomske nejednakosti i posebnog javnog konteksta mirovnih pokreta. Američko pravilo o izdvajanju nezakonitih dokaza tada se smatralo dijelom modernizma krivičnog postupka, ${ }^{63}$ ali su poslije liberalna nastojanja zaustavljena. ${ }^{64}$ Pravila izdvajanja u kasnijim razdobljima nisu proširivana, nego su, štaviše, sužavana brojnim iznimkama uz daljnje proširivanje ovlasti redarstva. ${ }^{65}$ Takva

\footnotetext{
${ }^{59}$ MOUNT, S., R v Shaheed: The Prima Facie Exclusion Rule Re-examined. New Zealand Law Review, 2003., str. 70 .

${ }^{60}$ Ibid., str. 49.

${ }^{61}$ TASLITZ, A., Reconstructing the Fourth Amendment, A History of Search and Seizure, NYU Press, New York, 2006., str. 65.

${ }^{62}$ Prije svega, misli se na odluku Saveznog vrhovnog suda Mapp v. Ohio (367 U.S. 643, 81 S.Ct. 1684, 6 L.Ed.2d 1081 (1961)). Međutim, Vrhovni sud Kalifornije je i ranije, u odluci People v. Martin (45 Cal.2d 755, 290 P.2d 855 (1955)), postavio ekskluzijsko pravilo o izdvajanju nezakonitih dokaza. LAFAVE, W.R., et al., op.cit. str. 501-502.

${ }^{63}$ KAHAN, D. M., MEARES, T. L. Foreword, The Coming Crisis of Criminal Procedure, Georgetown Law Journal, vol. 86, br. 5, Georgetown,1998., str. 1153.

${ }^{64}$ KLARMAN, M. et al. The Political Heart of Criminal Procedure: Essays on Themes of William J. Stuntz, Cambridge University Press, Cambridge, 2012., str. 4.

${ }^{65}$ ARENELLA, P. Rethinking the Functions of Criminal Procedure, The Warren and Burger Courts' Competing Ideologies, Georgetown Law Journal, vol. 72, Georgetown, 1983., str. 221. ISRAEL, J. Criminal Procedure, The Burger Court and the Legacy of the Warren Court. Michigan Law Review, vol. 75, 1977., str. 1319; SEIDMAN, L. Factual Guilt and the Burger Court: An Examination of Continuity and Change in Criminal Procedure. Colubia Law Review, vol. 80, 1980., str. 436, 442.
} 
su kretanja opravdana tezama da ekskluzijskom pravilu u savremenom krivičnom postupku nedostaje koherentno utemeljenje jer su uvjeti za liberalne reforme bili specifični, a u savremeno doba postoje drugačije potrebe. ${ }^{66}$

Prema gledištu profesora Kahana i Meares s Yalea, takve su doktrine nastale kao tadašnji napredni odgovor na političko i policijsko potlačivanje manjina, ali neke doktrine imaju svoje životne cikluse te, kada nestanu praktične potrebe i društvene nužnosti, postaju beskorisne. Potrebni su novi oblici djelovanja koji će biti prilagođeni savremenim problemima. Dio kritika tvrdi da savremeni krivični postupak ne uvažava nove političke mehanizme, kakvih sredinom 20. stoljeća nije bilo. ${ }^{67}$ Afričkoamerički profesor Kennedy s Harvarda smatra da su manjine sada previše izložene kriminalu od strane drugih pripadnika iste manjine i više ne postoji opasnost od bjelačkog policijskog nasilja kakvo je bilo povod uvođenju ekskluzijskog pravila. ${ }^{68}$ Zato smatra da bi izdvajanje nezakonitih dokaza trebalo prilagoditi drugim ciljevima. $^{69}$

Iako američki sustav naizgled pruža velike mogućnosti izdvajanja materijalnih dokaza, obim je ipak bitno sužen tokom više desetljeća nastajanja brojnih iznimaka i proširivanja policijskih ovlasti. ${ }^{70} \mathrm{~S}$ obzirom na to da veći dio tih iznimaka nije prihvaćen u našem uređenju, a američke policijske vlasti imaju šire ovlasti u prikupljanju dokaza, moglo bi se zaključiti da je naše uređenje strože od uzora. Primjerice, jedna od iznimaka je da se nezakoniti dokazi mogu koristiti za pobijanje okrivljenikove obrane jer počinitelj ne može imati zaštitu od neistina. ${ }^{71}$ Prema takvu pravilu, iz odluke Harris v. New York, 401 U.S. 222 (1971) važnija je vrijednost zaštita istine $u$ krivičnom postupku, odnosno vlast ne može upotrijebiti nezakonito prikupljene dokaze za utemeljenje činjenice (pozitivna uporaba), što ne znači pružanje okrivljenom mogućnost zaštite od neistina u njegovu iskazu, tako da se nezakoniti dokazi mogu koristiti za opovrgavanje (negativna uporaba). ${ }^{72}$

Pravilo o izdvajanju ne primjenjuje se u postupku koji se vodi pred istražnom porotom ( grand jury), ${ }^{73}$ koja može biti mjerodavna za teža krivična djela, poput organiziranog kriminala

\footnotetext{
${ }^{66}$ BRACEY, C. Truth and Legitimacy in the American Criminal Process, The Journal of Criminal Law and Criminology, vol. 90, br. 2, 2000., str. 691.

${ }^{67}$ MEARES, T. L. The Distribution of Dignity and the Fourth Amendment. u: Klarman, str. 124.

${ }^{68}$ KENNEDY, R. The State, Criminal Law, and Racial Discrimination, Harvard Law Review, vol. 107, br. 6, 1994., str. 1255-1278.

${ }^{69}$ KENNEDY, R. Race, crime, and the law, Vintage, New York, 1998., str. 187.

${ }^{70}$ KARAS, Ž., JUKIĆ, M., op.cit. str. 613.

${ }^{71}$ Harris v. New York, 401 U.S. 222 (1971.).

${ }^{72}$ LAFAVE, W.R., et al. op.cit., str. 510.

${ }^{73}$ MILES, C., The Exclusionary Rule, Georgetown Law Journal, vol. 90, 2002., str. 1276.
} 
ili korupcije. Pred istražnom porotom okrivljenik nema pravo na nazočnost branitelja, nema pravo na šutnju i ne primjenjuje se pravilo o izdvajanju nezakonitih dokaza. Tako, primjerice, pri istraživanju krivičnog djela korupcije nije uopće bitno je li pretraga bila nezakonita, nego jesu li pronađeni pouzdani dokazi. U američkom se pravu dokazi izdvajaju samo u odnosu na osobu kojoj su povrijeđena prava (npr. stanar pri pretrazi), dok se isti dokaz može koristiti u odnosu na druge osobe čija prava nisu izravno zahvaćena, prema pravilu iz Alderman v. United States, 394 U.S. 165 (1969). Ako je nezakonitim pretresom osumnjičenikova stana pronađen sporni predmet, to ne može biti izdvojeno u odnosu na druge saučinitelje. Kao osnova za takvo stajalište navodi se nepostojanje uporišta ili legitimiteta za traženje izdvajanja dokaza.

Američko je pravilo nastalo radi preveniranja nezakonitosti postupanja i zato se ne primjenjuje u slučajevima u kojima ne bi moglo ostvariti preventivno djelovanje. ${ }^{74} \mathrm{U}$ tom području postoji iznimka dobre vjere (good faith exception), utemeljena odlukom United States v. Leon 468 U.S. 897 (1984). ${ }^{75}$ Pavišić smatra da ta iznimka nije sasvim nesporna. ${ }^{76}$ Teorija o plodovima otrovne voćke također ima brojne iznimke. Ako je veza novih dokaza udaljena od prvotne povrede, koristi se teorija o uklonjenoj mrlji (purged taint doctrine). Iznimka je i neizbježno otkriće (inevitable discovery) ako bi podatak bio zasigurno otkriven drugim zakonitim načinima. ${ }^{77}$

Sužavanje je intenzivirano nakon što je predsjednik Vrhovnog suda SAD-a postao Roberts. ${ }^{78}$ Već početkom njegova mandata donesena je odluka Hudson v. Michigan 547 U.S. 586 (2006) kao jedna od najvažnijih odluka za daljnji pravac američkog razvoja. U tom je predmetu bila riječ o školskom slučaju nezakonite pretrage stana, kakvi su prema prijašnjoj sudskoj praksi bez dvojbe smatrani nezakonitima. Nezakonitom pretragom pronađeno je napunjeno oružje i veća količina droge. Sud je donio pravilo prema kojem se promatra bi li dokazi ionako bili pronađeni, neovisno o tome je li ulazak bio zakonit ili nije, te je, suprotno prijašnjim gledištima, naglasio da nepravilnosti pri traženju materijalnih dokaza nemaju poseban utjecaj na vjerodostojnost dokaza. U odluci Hudson ističe se poboljšanje policijskog profesionalizma u odnosu na nekadašnje doba, a kao zamjensko sredstvo umjesto izdvajanja

\footnotetext{
${ }^{74}$ CHOO, A., Evidence, Oxford University Press, Oxford, 2012., str. 185.

${ }^{75}$ KAMISAR, Y., Comparative Reprehensibility And The Fourth Amendment Exclusionary Rule, Michigan Law Review, Michigan, 1987., vol. 86, str. 6.

${ }^{76}$ PAVIŠIĆ, B. et.al, Komentar zakona o kaznenom postupku, Peto izdanje, Rijeka, Žagar, 2005., str 28.

${ }^{77}$ Nix v. Williams, 467 U.S. 431 (1984.).

${ }^{78}$ KARAS, Ž., JUKIĆ, M., op.cit, str. 614.
} 
postoji mogućnost korištenja pojedinačnim tužbama za konkretne povrede prava. Kao opravdanje za odmak od izdvajanja navode se i brojni prigovori ekskluzijskom pravilu. ${ }^{79}$

Brojni su autori zaključili da je Roberts time započeo ukidati pravilo o izdvajanju nezakonitih dokaza ${ }^{80}$ jer prijašnja pravila ne mogu opstati u smislenoj formi u duhu nove odluke. ${ }^{81}$ I prethodni predsjednik američkog Vrhovnog suda SAD-a Rehnquist primijetio je da je potrebna kontinuirana reevaluacija, te je predlagao sucima da razmotre što je od ekskluzijskog pravila uopće potrebno zadržati. Bradley smatra da to nije nepovoljan razvoj jer je već predlagao da američki sistem odbaci apsolutno izdvajanje, koje je univerzalno odbačeno, i da prihvati rješenje kakvo imaju civilizirane države. ${ }^{82}$ Prema pravilu iz odluke Hudson, izdvajanje ne bi bilo potrebno ako je zahvat bio suštinski (materijalno) opravdan, neovisno o tome jesu li poštivane formalnosti poput sudbenog naloga. Pokazala su se tačnima predviđanja da bi ta odluka mogla biti početak daljnjeg dopuštanja materijalnih dokaza prikupljenih povredama privatnosti te za usmjeravanje na alternativna sredstva, kakvima se inače mogu koristiti nedužne osobe kojima su povrijeđena ista prava. ${ }^{83}$

Prema novijoj sudskoj praksi, proširena je iznimka postupanja u dobroj vjeri. Najnoviji je slučaj na tom pravcu Davis v. United States, 131 S. Ct. 2419 (2011), u kojem su policijski službenici za pretraživanje suputnika u vozilu primijenili pravilo koje je bilo ukinuto, a sud je ipak utvrdio da su postupali u dobroj vjeri i nije izdvojio pronađeno oružje. U usporedbi s revolucijom pri donošenju pravila o izdvajanju nezakonitih dokaza, neki takav pristup nazivaju revolucionarnim sužavanjem. ${ }^{84}$ Daljnji bi razvoj mogao dovoditi do izdvajanja samo neosnovanih pretresa. ${ }^{85}$ Takve je promjene naznačio slučaj Herring v. United States, $129 \mathrm{~S}$. Ct. 695 (2009), u kojem je policijski službenik pretražio vozilo te pronašao drogu i oružje, pogrešno

\footnotetext{
${ }^{79}$ YACKLEY, J., Hudson v. Michigan: Has The Court Turned The Exclusionary Rule Into The Exclusionary Exception?. Hamline Law Review, vol. 30, 2007., str. 409-447.

${ }^{80}$ MACLIN, T., RADER, J. The Roberts Court Uses an Axe to Take Out the Fourth Amendment Exclusionary Rule, Mississippi Law Journal, vol. 81, 2012., str. 1183-1227.; BLAIR, C. Supreme Court Review Hudson v. Michigan: The Supreme Court Knocks and Announces the Demise of the Exclusionary Rule. Tulsa Law Review, vol. 42, 2007., str. 751-760.; DRIPPS, D. The Fourth Amendment, the Exclusionary Rule, and the Roberts Court. Chicago Kent Law Review, vol. 85, 2010., str. 209-239.

${ }^{81}$ LAFAVE, W., A Critique of the Supreme Court's Latest Assault on the Exclusionary Rule. Journal of Criminal Law and Criminology, vol. 99, 2009., str. 757.

${ }^{82}$ BRADLEY, C. Is the Exclusionary Rule Dead? Journal of Criminal Law and Criminology, vol. 102, 2012., str. 22.

${ }^{83}$ AMAR, A. R. The Rookie Year of the Roberts Court and a Look Ahead. Pepperdine Law Review, vol. 34. 2007.

${ }^{84}$ TOMKOVICZ, J. Davis v. United States: The Exclusion Revolution Continues. Ohio State Journal of Criminal Law, vol. 9, Ohio, 2011., str. 381.

${ }^{85}$ BRADLEY, C., cit. u bilj. 47., str. 211.
} 
smatrajući da postoji nalog za uhićenje osobe. Sud je u tom predmetu utvrdio da pravilo o izdvajanju dokaza nije namijenjeno za pogreške.

\subsection{Evropski kontinentalni sistem izdvajanja dokaza}

Apsolutno izdvajanje nezakonitih materijalnih dokaza nije u važnijim evropskim državama zastupljeno kao sredstvo koje bi bilo namijenjeno povredama u prikupljanju dokaza. Mreža stručnjaka koja je u okviru Direktorata za pravosuđe i unutarnje poslove Evropske komisije istraživala ovo područje zaključila je da se u sedam evropskih država nezakoniti dokazi načelno ne izdvajaju (Engleska, Francuska, Njemačka, Austrija, Švedska, Danska, Finska), dok u drugu skupinu spadaju države u kojima se dokazi u načelu izdvajaju (Španjolska, Grčka, Italija, Cipar, Malta i dr.), ali se ni u toj skupini nezakoniti dokazi ne izdvajaju na apsolutan način, nego se kombinirano koristi neki oblik razmjernosti ili uvažavanja okolnosti pojedinačnog slučaja (tzv. vaganje - balancing). ${ }^{86}$ Velika razlika postoji u odnosu prema nezakonitim personalnim i materijalnim dokazima. ${ }^{87}$

Iako u povijesti evropskog kontinentalnog prava odavno postoje različiti oblici izdvajanja dokaza, oni nisu bili usmjereni na način prikupljanja dokaza i nisu se opširno bavili materijalnim dokazima. ${ }^{88} \mathrm{U}$ akuzatornom (adversarial) postupku sud nije uključen u traženje dokaza nego samo donosi odluku na temelju materijala koji predstavljaju stranke. Izdvajanje dokaza tada ima drugačiji smisao jer neće biti predstavljen poroti, ali u inkvizitornom je sud upoznat s dokazom, a ipak ga mora zanemariti, što Damaška smatra izletom u nerealno. ${ }^{89}$ Povijesno gledano, zato je evropsko kontinentalno pravo, za razliku od anglosaksonskog prava, imalo manje dokaznih pravila. ${ }^{90}$ Pravila o izdvajanju dokaza nastala su kao posljedica razvoja stranačnosti i uloge odvjetnika u akuzatornim postupcima, odnosno nastojalo se ograničiti moć države kako bi se spriječilo da dospije u superiorni položaj iz kojega bi mogla utjecati na ishod postupka. $^{91}$

\footnotetext{
${ }^{86}$ EU Network of Independent Experts on Fundamental Rights, Opinion on the status of illegally obtained evidence in criminal procedures in the Member States of the European Union, CFR-CDF, 2003., str. 7.

${ }^{87}$ BRADLEY, C., cit. $u$ bilj. 47., str. 211-238.

${ }^{88}$ BELING, E., Die Beweisverbote als Grenzen der Wahrheitserforschung im Strafprozess, Schletter'sche Buchhandlung, Breslau, 1903.

${ }^{89}$ DAMAŠKA, M. Evidence Law Adrift, New Haven: Yale University Press, 1997., str. 48.

${ }^{90}$ DUFF, A. et al. The Trial on Trial, Truth and due process, Hart Publishing, Oxford, 2004., str. 138.

${ }^{91}$ VOGLER, R. et al. A World View of Criminal Justice - International And Comparative Criminal Justice, Ashgate Publishing, Surrey, 2005., str. 130; LANGBEIN, J. The Origins of Adversary Criminal Trial,Oxford University Press, Oxford, 2003., str. 119., 332.
} 
U austrijskom je sistemu prema zakonskom uređenju i sudskim tumačenjima načelno dopušteno korištenje materijalnim dokazima koji su prikupljeni nezakonitim postupanjem. ${ }^{92} \mathrm{Za}$ prihvaćanje nezakonitih dokaza kao opravdanje se navodi slučaj Schenk pred ESLJP-om, u kojem protuzakonito pribavljena snimka nije izdvojena. ${ }^{93} \mathrm{Za}$ ocjenu dokazne zabrane primjenjuje se teorija uspoređivanja, kojom se razmatraju okolnosti pojedinačnih slučajeva i utjecaj koji imaju na ravnotežu društvenih težnja. Primjena razmjernog pristupa potaknuta je raznolikošću povreda jer je drugačija važnost ako redarstvo nekomu svjesno iznuđuje iskaz ili je riječ o povredi za koju službenik opravdano nije mogao znati. U teoriji su prihvaćeni i drugi dosezi njemačke dogmatike, tako da se primjenjuje i raspodjela prava kao u njemačkoj teoriji o pravnim krugovima. ${ }^{94}$

Slično je stanje i u Švicarskoj, gdje se primjenjuje staro Walderovo mišljenje da nije potrebno izdvojiti svaki dokaz koji je nezakonito prikupljen, koji potječe od nepoštivanja zakona ili krivičnog djela, nego je potrebno razmotriti pojedinosti svakog slučaja i utvrditi je li nezakonitost takva da je potrebno nametnuti zabranu. Sudovi u skladu s time primjenjuju uspoređivanje uključenih težnji. ${ }^{95}$ Sudska praksa ne prihvaća zabranu izvođenja nezakonitih dokaza kao obavezu koja bi se trebala primjenjivati pri formalnim propustima. ${ }^{96}$ Potporu nalaze u judikaturi ESLJP-a pozivajući se na odluku Khan, u kojoj je utvrđeno da nije nužna apsolutna dokazna zabrana u krivičnom postupku. ${ }^{97}$

$\mathrm{U}$ francuskom pravu za propuste pridržavanja zakonitosti u provedbi radnje ne primjenjuje se izdvajanje dokaza, nego takve povrede potpadaju pod primjenu ništetnosti. Za izričito određene ništavosti (nullités textuelles) zakonski je određeno pri kojim će povredama radnja biti ništetna. Primjena nije apsolutna nego se poništavanje može primijeniti ako je riječ o suštinskim povredama, osobito pravima odbrane, za što se mora dokazati šteta za interese okrivljenika, odnosno da je uzrokovala povredu interesa stranke. ${ }^{98}$ Potrebno je postići najbolju moguću ravnotežu između ciljeva društva i pojedinaca. ${ }^{99}$ Zbog rijetkosti primjene, ustanova

\footnotetext{
${ }^{92}$ SEILER, S. Strafprozeßrecht, Universitätsverlag, Wien, 2000., str. 115.

${ }^{93}$ OGH 15Os3/92-8 od 02.06.1992. godine.

94 PILNACEK, C. Überblick über die Grundsätze der Beweisermittlung und der Beweisverbote im österreicheischen Strafverfahren u: Höpfel, F., Huber, B. Beweisverbote in Ländern der EU und vergleichbaren Rechtsordnungen, Max-Planck Institut, Freiburg, 1999., str. 114.

${ }^{95}$ WALDER, H. Rechtswidrig erlangte Beweismittel im Strafprozess, Schweizerische Zeitschrift für Strafrecht, Stampfli Verlag AG, Bern, 1966., str. 36.

${ }^{96}$ BGE 96 I 437 od 04.11.1970.

97 8G.55/2000 od 14. marta 2001.

${ }^{98}$ RENUCCI, J-F. Code de Procédure Pénale, Dalloz, Paris, 2005., str. 1256.

${ }^{99}$ GUINCHARD, S., BUISSON, J. Procédure Pénale, Litec, Paris, 2002., str. 992.
} 
ništetnosti nije teorijski razrađena i prigovara joj se da ima nesigurne osnove koje ne omogućuju određenije razmatranje. ${ }^{100}$

Niži sudovi imaju ograničene mogućnosti izdvajanja nezakonitih dokaza. Slično francuskom sistemu i Nizozemska se koristi diskrecijskim izdvajanjem, u kojem promatra svrhu koju je imala povrijeđena odredba. ${ }^{101}$

Belgija također spada među rijetke razvijene države koje su uvele apsolutno izdvajanje nezakonitih materijalnih dokaza. Ustavni sud Belgije je 2003. godine ukinuo takav model smatrajući da apsolutno izdvajanje koje je uvedeno 1990. godine daje disproporcionalne rezultate, a naznake odustajanja od apsolutnog izdvajanja u sudskoj su se praksi pokazivale i prije. Odluka koja je pridonijela promjeni stajališta belgijskog sistema jest slučaj Antigoon. ${ }^{102}$ Sud je u tom predmetu utvrdio da je izdvajanje nezakonitih dokaza potrebno samo u iznimnim okolnostima, ako je riječ o izostavljanju nekog važnog dijela postupka koji dovodi do ništetnosti, odnosno ako je narušena pouzdanost dokaza ili ako je riječ o narušavanju pravičnosti cijelog suđenja. Slučaj se odnosi na nezakonitu policijsku akciju u kojoj je pretražen osumnjičenik. U džepu jakne tom mu je prigodom pronađen ključ kojim su službenici otvorili vozilo i ondje pronašli sporno vatreno oružje. Kasacijski sud je utvrdio da nepravilnosti u pretrazi ne utječu na vjerodostojnost pronađenog oružja te da posrijedi nije namjerno i ozbiljno narušavanje interesa okrivljenika. Ta je odluka donesena pod utjecajem konvencijske judikature te se kao opravdanje navode odluke ESLJP-a u predmetima Schenk i Khan, a uz to se spominje francuska te nizozemska sudska praksa i Rimski statut MKS. ${ }^{103}$

Slično je u slučaju Davies policija nezakonito ušla na privatni posjed i pronašla veliku količinu droge. Sud je utvrdio da, iako je dio pretrage bio nezakonit, time nije narušena vjerodostojnost pronađenih dokaza niti postoje ikakve sumnje u njihovu pouzdanost ili tačnost. U istom je slučaju ESLJP ${ }^{104}$ potvrdio da je okrivljenik imao mogućnost provjeriti točnost prikupljenih dokaza, i to postaviti kao pitanje u krivičnom postupku te da nije povrijeđena pravičnost postupka. ${ }^{105}$ Iako neki autori navode da se Nizozemska možda također koristila apsolutnim pravilom o izdvajanju pa je zatim odustala, ${ }^{106}$ tamošnji autori tvrde da se

\footnotetext{
100 STEFANI, G., LEVASSEUR, G., Procédure Pénale, Dalloz, Paris 2004., str. 720.

101 THAMAN, S., The Exclusionary Rule, 2012., u: BROWN, K. B. et al. General Reports of the XVIIIth Congress of the International Academy of Comparative Law, Springer, str. 670.

${ }^{102}$ Cour de cassation de Belgique, br. P.03.0762.N/1 od 14.10.2003.

103 Conclusions de Monsieur l'avocat général De Swaef.

${ }^{104}$ Evropski sud za ljudska prava, Lee Davies protiv Belgije, broj 18704/05, stav 41, 28.06.2009. godine.

${ }^{105}$ ROSIER, K. La Cour européenne des droits de l'homme confrontée à la jurisprudence Antigone, Bulletin social et juridique, br. 423, 2010., str. 6 .

106 ŠUGMAN, K., Dokazne prepovedi v kazenskem postopku, Bonex, Ljubljana, 2000., str. 248.
} 
nizozemski sistem nikada nije koristio automatskim pravilom sličnim američkomu jer se za propuste u provođenju radnja mogu koristiti disciplinske ili krivične sankcije prema odgovornim službenicima. ${ }^{107}$

Irska je, osim Sjedinjenih Država, jedina anglosaksonska država koja se djelomice koristi apsolutnim izdvajanjem, ali samo za ustavne povrede i ako je riječ o namjernom i svjesnom postupanju. ${ }^{108}$ Izdvajanje se ne primjenjuje ako službenik nije bio svjestan povrede, ako je pogriješio ili je općenito bila riječ o postupanju u dobroj vjeri. ${ }^{109}$ Čak i takvo usko pravilo izvrgnuto je primjedbama teoretičara. ${ }^{110}$ Thaman zbog takva stanja smatra da je sudska praksa preokrenula apsolutno izdvajanje u relativno u talijanskom, španjolskom ili grčkom sudstvu, a ujedno i u irskom u odnosu na neke dokaze. ${ }^{111} \mathrm{U}$ nekim uporednim analizama ističe se da se turski sistem koristi apsolutnim izdvajanjem. Međutim, turska sudska praksa za potrebe izdvajanja uvela je razliku između nezakonitog i ilegalnog postupanja u prikupljanju dokaza te izdvaja samo posljednje. Pri radnjama pretrage i sličnima nisu propisane ex lege osnove za izdvajanje dokaza. ${ }^{112}$

U njemačkom su sistemu dokazne zabrane pri pretragama i sličnim radnjama prikupljanja materijalnih dokaza vrlo uske, mogu se koristiti samo kada je riječ o težim propustima ili narušavanju najosjetljivijih prava, a ne i za obične formalnosti u radnjama. ${ }^{113}$ Njemački se sistem kao osnovom koristi teorijom pravnih krugova (Rechtskreistheorie), nastalom 1964. godine odlukom Saveznog vrhovnog suda BGHSt 19, 325, kojom se prava raspoređuju u tri područja (kruga). Najveća je zaštita omogućena u području osobnog života i dostojanstva, odnosno intimnom području (Intimsphäre) ${ }^{114}$ koje se ne može izlagati zahvatima tijela vlasti. ${ }^{115}$ Kao primjer te skupine navodi se intimni bračni život ${ }^{116}$ ili razgovor supružnika u njihovoj

\footnotetext{
${ }^{107}$ JEROEN, M. J. C. et al. Introduction to Dutch Law, Nederlandse Vereniging voor Rechtsvergelijking, Alphen aan den Rijn: Kluwer Law International, 2006., str. 441; EMBREGTS, M., Similarities and Differences: the Operation of the Exclusionary Rule in the US, Germany and the Netherlands, 2000., u: BREUR, C. et al., New Trends in Criminal Investigation and Evidence, Antwerpen: Intersentia.

${ }^{108}$ People v. O'Brien [1965] I.R. 142 (Ir. 1964), dostupno na: www.supremecourt.iel.

${ }^{109}$ People (DPP) v Kenny [1990], dostupno na:

www.supremecourt.ie/.

${ }^{110}$ DALY, Y. M. Unconstitutionally Obtained Evidence in Ireland: Protectionism, Deterrence and The Winds of Change. Irish Criminal Law Journal, 2009., vol. 19,; HEFFERNAN, L. Police Accountability And The Irish Law Of Evidence. Crime, Law and Social Change, 2011., vol. 55, br. 2-3.

111 THAMAN, S., op.cit. str. 688.

112 JELANI, J., Turkish Criminal Procedure Code, Beta, İstanbul, 2009., str. 119.

${ }^{113}$ CRAMER, S., BÜRGLE, M. Die Strafprozessualen Beweisverwertungsverbote, Boorberg, Stuttgart, 2004., str. 118; ROXIN, C. Strafverfahrensrecht, Beck, München, 1998., str. 299.

${ }^{114}$ Ibid., str. 193.

115 KÖHLER, M. Prozeßrechtsverhältnis und Ermittlungseingriffe, Zeitschrift für die gesamte Strafrechtswissenschaften. vol. 101, br. 1, 1995., str. 31.

${ }^{116}$ BEULKE, W. Strafprozeßrecht, Müller, Heidelberg, 2000., str. 230.
} 
sobi. ${ }^{117}$ Druga skupina obuhvaća prava privatnosti (Privatsphäre), i u slučaju nezakonitih dokaza koji se odnose na njih potrebno je utvrditi razmjernost koristeći se teorijom uspoređivanja ili vaganja (Abwägungslehre). Vaganje se provodi usporedbom okolnosti koje podupiru sučeljene ciljeve krivičnog gonjenja ili zaštite prava građana ${ }^{118}$ Primjerice, nezakonita snimka razgovora bila je dopuštena za krivično djelo podmetanja požara, dok je drugačije bilo odlučeno kada je istovrsni dokaz bio usmjeren na lakše krivično djelo. ${ }^{119}$ Čak ni pri primjeni dokazne zabrane njemački se sistem ne koristi izdvajanjem, nego dokazi ostaju u spisu, ali se ne smiju koristiti u obrazloženju presude. Osim teorije pravnih krugova, mogu se koristiti i druge osnove, poput načela pravne države ili načela pravičnosti, ali se one najčešće koriste u slučaju personalnih dokaza.

\subsection{Položaj nezakonitih dokaza u Republici Hrvatskoj}

U novom Zakonu o kaznenom postupku Republike Hrvatske član 10. glasi:

„(1) Sudske se odluke ne mogu temeljiti na dokazima pribavljenim na nezakonit način (nezakoniti dokazi).

(2) Nezakoniti su dokazi: 1) koji su pribavljeni kršenjem Ustavom, zakonom ili međunarodnim pravom propisane zabrane mučenja, nečovječnog ili ponižavajućeg postupanja, 2) koji su pribavljeni povredom Ustavom, zakonom ili međunarodnim pravom zajamčenih prava obrane, prava na ugled i čast, te prava na nepovredivost osobnog i obiteljskog života, osim u slučaju stavka 3. ovog članka, 3) koji su pribavljeni povredom odredaba kaznenog postupka i koji su izričito predviđeni ovim Zakonom, 4) za koje se saznalo iz nezakonitih dokaza.

(3) Ne smatraju se nezakonitim dokazi pribavljeni povredom prava i sloboda iz stavka 2. točke 2. ovog članka u postupku za teške oblike kaznenih djela iz nadležnosti Županijskog suda kod kojih interes kaznenog progona i kažnjavanja počinitelja preteže nad povredom prava.

\footnotetext{
${ }^{117}$ SCHROEDER, F. C., Strafprozeßrecht., Beck, München, 2001., str. 74.

118 ROGALL, K. Gegenwärtiger Stand und Entwicklungstendenzen der Lehre von den strafprozessualen Beweisverboten, Zeitschrift für die gesamte Strafrechtswissenschaften, vol. 91, br. 1, 1979., str. 11.

${ }^{119}$ ROXIN, C., op.cit., str. 192.
} 
(4) Sudska odluka ne može se temeljiti isključivo na dokazu iz stavka 3. točke 2. ovog članka." $" 120$

Dakle, novi hrvatski Zakon o kaznenom postupku dodatno normira način na koji Sud ocjenjuje treba li pojedine dokaze izdvojiti tako da u sistemu nezakonitih dokaza postoje dva načina izdvajanja:

- za sve povrede koje imaju izričito u ZKP-u propisanu posljedicu nezakonitost dokaza (propisane povrede) i dalje se primjenjuje apsolutno izdvajanje, dok se relativno izdvajanje odnosi isključivo na povrede koje nisu izričito zakonski propisane, te na povrede u postupku za teške oblike krivičnih djela iz nadležnosti Županijskog suda kod kojih je interes za progon $i$ kažnjavanje počinioca ovih djela preteže u odnosu na jačinu i narav povrede njihovih prava $i$ sloboda iz stava 2. tačke 2) člana 10. ovog Zakona

Ovom odredbom zakonodavac uvodi načelo razmjernosti kroz teoriju o ,vaganju“ (po uzoru na njemački sistem) povrede ljudskih prava s jedne strane is druge strane javnog interesa krivičnog progona i kažnjavanja počinitelja krivičnog djela.

\subsection{Položaj nezakonitih dokaza u Republici Srbiji}

U članu 16. stav 1. srbijanskog Zakonika o krivičnom postupku dan je pojam nezakonitih dokaza. Prema navedenoj odredbi, sudske odluke se ne mogu zasnivati na dokazima koji su, neposredno ili posredno, sami po sebi ili prema načinu pribavljanja u suprotnosti sa Ustavom, ovim zakonikom, drugim zakonom ili opšteprihvaćenim pravilima međunarodnog prava i potvrđenim međunarodnim ugovorima, osim u postupku koji se vodi zbog pribavljanja takvih dokaza.

Prema odredbi člana 84. ZKP Srbije, ${ }^{121}$ dokazi koji su pribavljeni protivno članu 16. stav 1. ovog zakonika (nezakoniti dokazi) ne mogu biti korišteni u krivičnom postupku.

Dakle, srbijanski zakonodavac za propisane povrede koje imaju za posljedicu nezakonit dokaz primjenjuje apsolutni sistem izdvajanja nezakonitog dokaza.

\footnotetext{
${ }^{120}$ Zakon o kaznenom postupku Republike Hrvatske, Narodne novine, br. 152/08, 76/09, 80/11, 121/11, 91/12, 143/12, 56/13, 145/13, 152/14 i 70/17 (dalje u tekstu ZKP RH).

${ }^{121}$ Zakonik o krivičnom postupku Republike Srbije, Službeni glasnik RS, br. 72/11, 101/11, 121/12, 32/13, 45/13

i 55/14, (dalje u tekstu ZKP R Srbije).
} 
Nezakoniti dokazi se izdvajaju iz spisa, stavljaju u poseban zapečaćeni omot i čuvaju kod sudije za prethodni postupak do pravnosnažnog okončanja krivičnog postupka, a nakon toga se uništavaju i o tome se sastavlja zapisnik. Izuzetno nezakoniti dokazi se čuvaju do pravnosnažnog okončanja sudskog postupka koji se vodi zbog pribavljanja takvih dokaza.

Jedna od funkcionalnih nadležnosti vijeća na glavnom pretresu jeste i izdvajanje nezakonitih dokaza na istom. Vijeće će rješenjem odlučiti da se iz spisa izdvoje i odvojeno čuvaju dvije grupe ovih pismena. Prvo to su zapisnici o ranijem ispitivanju lica koja su oslobođena dužnosti svjedočenja pod daljnjim uslovom da nisu uopšte pozvana na glavni pretres ili su na glavnom pretresu izjavili da neće da svjedoče. ${ }^{122}$ Drugo, to su obavještenja ili zapisnici koji ne mogu biti korišteni u krivičnom postupku u skladu sa članom 237. st. 1. i 3. Zakonika.

Osim toga, ukoliko stranke, branilac ili oštećeni do završetka glavnog pretresa predlože izvođenje dokaza koji je nezakonit, predsjednik vijeća će odbiti prijedlog obrazloženim rješenjem. $^{123}$

\section{Praksa Evropskog suda za ljudska prava i Ustavnog suda Bosne i Hercegovine}

\subsection{Evropska konvencija za zaštitu ljudskih prava i temeljnih sloboda i praksa Evropskog suda za ljudska prava}

Konvencijsko pravo ne uređuje područje dopustivosti dokaza, nego se odnos prema nezakonitim materijalnim dokazima promatra u okviru procjene pravičnosti suđenja. ${ }^{124}$ Ako se u krivičnom postupku koriste materijalni dokazi prikupljeni povredom domaćih pravnih pravila ili povredom konvencijskih odredaba koje uređuju temeljna prava u okviru radnja prikupljanja materijalnih dokaza, ${ }^{125}$ prema načelnom stajalištu ESLJP, samim time ne narušava se pravičnost postupka niti je dokaze potrebno obavezno izdvajati. ${ }^{126}$ ESLJP uvažava sve okolnosti slučaja i promatra je li vjerodostojnost dokaza narušena načinom prikupljanja i je li

\footnotetext{
122 BEJATOVIĆ, S., Krivično i procesno pravo, treće izmenjeno i dopunjeno izdanje, JP Službeni glasnik, Beograd, 2014., str. 457.

123 Clan 395. stav 3. u vezi sa stavom 1. ZKP R Srbije.

${ }^{124}$ KARAS, Ž. Odnos Europskog suda za ljudska prava prema nezakonitim policijskim dokazima, Pravni vjesnik, br. 3-4, Osijek, 2006., str. 113-125.

${ }^{125}$ STONE, R., Civil Liberties and Human Rights, Oxford University Press, Oxford, 2012., str. 175.

${ }^{126}$ Schenk pr. Švicarske, br. 10862/84, 12.06.1988.
} 
vjerodostojnost bila provjerena u krivičnom postupku. ${ }^{127}$ Ako je okrivljenik imao prikladne mogućnosti propitivanja pouzdanosti materijalnog dokaza korištenjem prava odbrane, povreda neće ostvariti nepravičnost postupka. ${ }^{128} \mathrm{U}$ tom se smislu ESLJP u procjeni utjecaja pojedinih dokaza na pravičnost postupka ne koristi apsolutnim pristupom, nego promatra sve okolnosti slučaja kao dio relativnog pristupa. Države, također, nemaju obavezu korištenja apsolutnim izdvajanjem nezakonitih materijalnih dokaza da bi se ostvarila pravičnost postupka niti je potrebno široko odrediti opseg povreda na koje bi se izdvajanje dokaza trebalo primjenjivati.

Prva odluka koja se bavila pitanjem utjecaja nezakonito prikupljenih dokaza na suđenje jest Schenk protiv Švicarske o slučaju nezakonite snimke razgovora o naručivanju ubistva. ${ }^{129} \mathrm{U}$ toj je odluci ESLJP istaknuo da na načelnoj i općenitoj razini ne zabranjuje mogućnost sudske uporabljivosti dokaza prikupljenih nezakonitim postupanjem. ESLJP je istovjetno stajalište dosljedno imao u svim slučajevima u kojima su zahtjevi podnošeni zbog korištenja nezakonitim dokazima, primjerice u slučaju Khan o nezakonitom prisluškivanju razgovora. ${ }^{130}$ Drugačije je stanje s povredama nederogabilnih prava, poput zabrane mučenja, ${ }^{131}$ za što je ESLJP utvrdio da narušava pravičnost (a isto je i sa slučajevima poticanja od strane agenta provokatora). ${ }^{132}$ Razlika proizlazi iz drugačijeg statusa, odnosno iz mogućnosti konvencijskog ograničavanja prava privatnosti zbog opravdanih razloga, dok sličnog ograničavanja zabrane mučenja nema. Povreda zabrane mučenja, neljudskog i ponižavajućeg postupanja iz čl. 3. EKLJP-a povlači ozbiljna pitanja o pravičnosti postupka, neovisno o tom je li riječ o personalnim ili materijalnim dokazima. $^{133}$

Neovisno o tome što su ovdje predmet promatranja radnje kojima se prikupljaju materijalni dokazi, povreda nederogabilnog prava, kao što je zabrana mučenja tijekom ispitivanja također može utjecati na pravičnost prikupljenih materijalnih dokaza. Iako se većina takvih slučaja pred ESLJP-om odnosi na pribavljanje iskaza, primjerice Harutyunyan ${ }^{134}$ ili Levinţa, ${ }^{135}$ postoje i slučajevi u kojima je bila riječ o pribavljanju materijalnih dokaza. U

\footnotetext{
127 JACKSON, J. D., SUMMERS, S. J. (2012). The Internationalisation of Criminal Evidence: Beyond the Common Law and Civil Law Traditions, Cambridge University Press, Cambridge, 2012., str. 149., 181.

${ }^{128}$ KEANE, A., MCKEOWN, P., The Modern Law of Evidence, Oxford University Press, Oxford, 2012., str. 75. ${ }^{129}$ Schenk protiv Švicarske, br. 10862/84, 12. jula 1988.

${ }^{130}$ Khan protiv Ujedinjenog Kraljevstva, br. 35394/97, 12. maja 2000.

${ }^{131}$ Göcmen protiv Turske, br. 72000/01, 17. oktobra 2006.

132 Teixeira De Castro protiv Portugala, br. 25829/94, 09.06.1998.

${ }^{133}$ U Konvenciji Ujedinjenih naroda protiv mučenja i drugih oblika neljudskog i ponižavajućeg postupanja u čl. 15. propisana je zabrana korištenja iskazima pribavljenima iznuđivanjem.

${ }^{134}$ Harutyunyan protiv Armenije, 36549/03, 28. juna 2007. AMBOS, K., The Transnational Use of Torture Evidence, Israel Law Review, vol. 42, 2009, str. 362-397.

${ }^{135}$ Levinţa protiv Moldavije, br. 17332/03, 16. decembra 2008.
} 
predmetu Jalloh protiv Njemačke istražitelji su nasilno dali osumnjičeniku sredstvo za povraćanje da bi došli do progutanog paketića droge. ${ }^{136}$ Prema odluci ESLJP-a, koji je promatrao sve okolnosti postupanja, u ovom slučaju javni interes za krivičnim gonjenjem nije bio prevladavajući jer je osumnjičenik bio ulični preprodavač s malim količinama droge, iako načelno nije zabranjeno nasilno izuzimanje pojedinih uzoraka od osumnjičenika. ${ }^{137} \mathrm{U}$ slučaju Gäfgen protiv Njemačke ESLJP je utvrdio da materijalni dokazi prikupljeni zlostavljanjem i povredom čl. 3. EKLJP-a o zaštiti od mučenja, neljudskog ili ponižavajućeg postupanja ne bi trebali biti osnova za presudu. ${ }^{138} \mathrm{U}$ tom je predmetu dio sudaca u izdvojenom mišljenju smatrao da ESLJP pravi nepotrebnu razliku između iskaza i materijalnih dokaza prikupljenih povredom čl. 3. jer je riječ o apsolutnom pravu. ${ }^{139}$ Primjena neljudskog ili ponižavajućeg postupanja ne znači izravno narušavanje pravičnosti, nego se razmatraju sve okolnosti slučaja.

U praksi ESLJP-a znatan utjecaj ima vjerodostojnost nezakonitih dokaza. U predmetu Lisica protiv Hrvatske ${ }^{140}$ podnesen je zahtjev s tvrdnjom da su policijski službenici u razdoblju između dviju pretraga ušli u sporno vozilo i time narušili vjerodostojnost poslije pronađenog dokaza. Sporni ulazak u vozilo bio je proveden kao izvidna radnja kriminalističko-tehničkog pregleda s ciljem izuzimanja vlakana sa sjedala. ESLJP je zaključio da su službenici bili u vozilu bez znanja okrivljenika ili njegova branitelja, iako nije bilo posebnog razloga da ne budu obaviješteni o provođenju te radnje, i zato je dokaz pronađen kasnijom pretragom smatrao upitno vjerodostojnim. ESLJP je poglavito promatrao utjecaj prava obrane na vjerodostojnost dokaza, a ne pitanje je li ulazak u vozilo bio zakonit, niti je li u konačnici obavještavanje osumnjičenika uvjet zakonitosti takvih radnja prema hrvatskom pravu.

\subsection{Praksa Ustavnog suda Bosne i Hercegovine}

Pitanje nezakonitih dokaza u praksi Ustavnog suda Bosne i Hercegovine postavljalo se u okviru prava na pravično suđenje iz člana II/3.e) Ustava Bosne i Hercegovine i člana 6. stav 1. Evropske konvencije.

\footnotetext{
136 Jalloh protiv Njemačke, br. 54810/00, 11. jula 2006.

${ }^{137}$ WHITE, R. et al., The European Convention on Human Rights, Oxford University Press, Oxford 2010., str. 287.

${ }^{138}$ Gäfgen protiv Njemačke, br. 22978/05, 1. juna 2010.

${ }^{139}$ MOWBRAY, A. Cases Materials and Commentary on the European Convention on Human Rights, Oxford University Press, Oxford, 2012., str. 423.

${ }^{140}$ Lisica protiv Hrvatske, br. 20100/06, 25. februara 2010. dostupno na:
} 
Zadatak Ustavnog suda nije da daje svoju ocjenu o prihvatljivosti dokaza umjesto domaćih sudova, iako može ispitivati način na koji se s tim dokazima postupalo kao bitnim elementom pri odlučivanju da li je suđenje bilo pravično, te su tako pravila o dokazima uglavnom pitanje za domaće sudove. ${ }^{141}$

U odnosu na pravičnost dokaza i njihovo korištenje, sud pridaje značaj sljedećem: 1) da li je podnositelj predstavke dobio mogućnost da osporava autentičnost dokaza i da se suprotstavi njihovoj upotrebi; i 2) kvalitet dokaza, uključujući i da li okolnosti pod kojima su pribavljeni dokazi bacaju sumnju na njihovu vjerodostojnost i tačnost. ${ }^{142}$

U predmetu AP 312/04 od 23. septembra 2005., ${ }^{143}$ apelant je, inter alia, prigovorio da se u osporenoj presudi koriste dokazi koje je prikupila policija pri vršenju uviđaja koji su, navodno, bili nezakoniti prema odredbama tadašnjeg Zakona o krivičnom postupku. U vezi s tim apelant navodi da istražni sudija nije mogao ovlastiti policiju da nastavi vršiti uviđaj koji je on započeo, te da su zbog toga nezakoniti svi materijalni dokazi nađeni pri vršenju uviđaja (čahure i dijelovi zrna), kao i ostali dokazi koje je predočila policija (zapisnik o izvršenom uviđaju, fotodokumentacija i skica mjesta događaja, službene zabilješke policajaca i sl.). Zadatak Ustavnog suda je da ispita da li su pri donošenju osporene presude poštivani standardi člana 6. Evropske konvencije u pogledu korištenja dokaza na kojima se presuda zasniva. Ustavni sud je naglasio da, u principu, svi dokazi na kojima se temelji presuda moraju biti izvedeni u prisustvu optuženog. Korištenje izjava i drugih materijalnih dokaza koji su prikupljeni prije suđenja kao dokaznog materijala, u principu, nije nekonzistentno sa standardima člana 6. Evropske konvencije sve dok se poštuju prava odbrane. Prema ovim pravima, optuženi ima mogućnost da pokuša osporiti navode optužbe, kao i da ispituje svjedoke u nekoj od faza suđenja. U konkretnom slučaju svi dokazi na kojima se temelji osporena presuda izvedeni su na glavnom pretresu, kome su bili prisutni apelant i njegov branilac, te nema

\footnotetext{
${ }^{141}$ Ovakav stav Ustavnog suda prati praksu Evropskog suda za ljudska prava (Schenk protiv Šicarske, presuda od 12. jula 1988. godine, broj predstavke 1086/84, serija A-140, stav 49). U ovoj odluci Evropski sud je izrazio stav da član 6. Evropske konvencije ne sadrži niti jedno pravilo koje regulira pitanje prihvatljivosti dokaza, nego da je to pitanje u isključivoj nadležnosti domaćeg zakonodavstva, te da, u skladu sa navedenim, prihvatanje nezakonitih dokaza ne znači samo po sebi povredu člana 6. Evropske konvencije, da Evropski sud ispituje postupak kao cjelinu, odnosno da li su sudovi, korištenjem tog nezakonitog dokaza, lice lišili prava na pravično suđenje, te da se posebno ocjenjuje da li je taj nezakoniti dokaz bio jedini dokaz na kojem su sudovi zasnivali svoju odluku. Vid. i Evropski sud za ljudska prava, Pronina protiv Rusije, Odluka o dopustivosti od 30. juna 2005. godine, aplikacija broj $65167 / 01$.

142 Jalloh protiv Njemačke [GC], br. 54810/00. stav 96, ECHR 2006-IX.

${ }^{143}$ Odluka o meritumu, Službeni glasnik BiH, br. 80/05.
} 
nijednog razloga da se posumnja da se osporena presuda temelji na dokazima korištenim suprotno od standarda koje propisuje član 6. Evropske konvencije.

U ovom predmetu, Ustavni sud je u nekoliko navrata naglasio da u njegovoj nadležnosti nije da vrši ocjenu prihvatljivosti pojedinih dokaza umjesto redovnih sudova. ${ }^{144}$ Kako nisu utvrđene povrede, apelacija je odbijena kao neosnovana. ${ }^{145}$

U predmetu AP 3225/07 od 14. aprila 2010., ${ }^{146}$ Ustavni sud je usvojio apelaciju i utvrdio povredu prava na pravično suđenje iz člana II/3.e) Ustava Bosne i Hercegovine i člana 6. stav 1. Evropske konvencije za zaštitu ljudskih prava i osnovnih sloboda, jer su redovni sudovi zasnovali presudu na dokazima na kojima se presuda ne smije zasnivati, a Vrhovni sud nije obrazložio u kojoj je mjeri upotreba takvih dokaza utjecala na zakonitost presude, odnosno u kojoj je mjeri mogla dovesti u pitanje apelantovo pravo na pravično suđenje. Okolnosti konkretnog slučaja ukazuju na to da je ovdje posebno izražen zahtjev poštivanja principa „obrazložene odluke“ iz člana 6. Evropske konvencije zato jer se radilo o pravnom pitanju koje je od suštinskog značaja za ishod konkretnog predmeta. Ustavni sud je utvrdio povredu prava

\footnotetext{
${ }^{144}$ Ovakvu praksu je imao i Dom za ljudska prava smatrajući da „nije u nadležnosti Doma da procjenu domaćih sudova zamijeni vlastitom procjenom činjenica, ako takvi zaključci ne djeluju neprihvatljivo ili proizvoljno" (vidi Dom za ljudska prava, „Trgosirovina Sarajevo d.d. “ protiv Federacije BiH, predmet broj CH/01/4128, odluka o prihvatljivosti od 6. septembra 2000.).

${ }^{145}$ Slično je Ustavni sud odlučio i u predmetu AP 2523/05 od 20. oktobra 2006. (Odluka o dopustivosti i meritumu), Službeni glasnik BiH 14/07; predmetu AP 3181/06 od 26. februara 2009. (Odluka o dopustivosti; nije objavljena u Službenom glasniku); predmetu AP 523/07 od 2. decembra 2009. (Odluka o dopustivosti; nije objavljena u Službenom glasniku); predmetu AP 2239/07 od 14. aprila 2010. (Odluka o dopustivosti i meritumu) Službeni glasnik BiH 70/10; predmetu AP 412/08 od 29. juna 2010. (Odluka o dopustivosti; nije objavljena u Službenom glasniku); predmetu AP 813/08 od 21. jula 2010. (Odluka o dopustivosti; nije objavljena u Službenom glasniku); predmetu AP 1153/08 od 27. oktobra 2010. (Odluka o dopustivosti i meritumu), Sl. glasnik BiH, br. 24/11; predmetu AP 1316/08 od 8. decembra 2010. (Odluka o dopustivosti i meritumu), Sl. glasnik BiH, br. 47/11; predmetu AP 1507/08 od 8. decembra 2010. (Odluka o dopustivosti i meritumu), Sl. glasnik BiH, br. 48/11; predmetu AP 3581/08 od 20. aprila 2011. (Odluka o dopustivosti; nije objavljena u Službenom glasniku); predmetu AP 2585/08 od 12. oktobra 2011. (Odluka o dopustivosti; nije objavljena u Službenom glasniku); predmetu AP 2350/09 od 27. juna 2012. (Odluka o dopustivosti i meritumu) Službeni glasnik BiH, broj 75/12; predmetu AP 1235/09 od 19. jula 2012. (Odluka o dopustivosti i meritumu) Službeni glasnik BiH, broj 79/12; predmetu AP 1492/09 od 18. septembra 2012. (Odluka o dopustivosti i meritumu), Službeni glasnik BiH, broj 80/12; predmetu AP 2305/09 od 18. septembra 2012. (Odluka o dopustivosti i meritumu), Službeni glasnik BiH, broj 81/12; predmetu AP 2131/09 od 10. oktobra 2012. (Odluka o dopustivosti i meritumu), Službeni glasnik BiH, broj 96/12; predmetu AP 2826/09 od 10. oktobra 2012. (Odluka o dopustivosti i meritumu), Službeni glasnik BiH, broj 96/12; predmetu AP 51/10 od 14. februara 2013. (Odluka o dopustivosti i meritumu), Službeni glasnik BiH, broj 19/13; predmetu AP 1262/10 od 26. aprila 2013. (Odluka o dopustivosti; nije objavljena u Službenom glasniku); predmetu AP 2248/09 od 5. jula 2013. (Odluka o dopustivosti i meritumu), Službeni glasnik BiH, broj 77/13; predmetu AP 2246/10 od 5. novembra 2013. (Odluka o dopustivosti; nije objavljena u Službenom glasniku); predmetu AP 4162/10 od 12. februara 2014. (Odluka o dopustivosti i meritumu), Službeni glasnik BiH, broj 29/14; predmetu AP 1655/11 od 26. juna 2014. (Odluka o dopustivosti i meritumu), Službeni glasnik BiH, broj 71/14; predmetu AP 4007/11 od 25. juna 2014. (Odluka o dopustivosti i meritumu), Službeni glasnik BiH, broj 63/14; predmetu AP 1280/11 od 17. jula 2014. (Odluka o dopustivosti i meritumu), Službeni glasnik BiH, broj 74/14; predmetu AP 695/12 od 10. februara 2015. (Odluka o dopustivosti i meritumu; nije objavljena u Službenom glasniku).

${ }^{146}$ Odluka o dopustivosti i meritumu, Sl. glasnik BiH, br. 95/10.
} 
u slučaju iznude priznanja, ${ }^{147}$ korištenja tzv. slučajnih nalaza kod posebnih istražnih radnji, ${ }^{148}$ načina na koji su dokazi pribavljeni i upotrijebljeni u postupku protiv apelanta, što je utjecalo na postupak u cjelini, zbog čega u postupku nisu ispunjeni zahtjevi poštenog suđenja, ${ }^{149}$ pretresanja na osnovu usmene naredbe kada sudija za prethodni postupak propusti sačiniti zapisnik i predati ga sudu. ${ }^{150}$

\section{Zaključak}

Pojam nezakonitih dokaza izaziva mnoge teorijske rasprave i sporove i jedan je od središnjih pojmova savremenog krivično procesnog zakonodavstva, a zakonitost u prikupljanju dokaza ima krucijalan značaj u pogledu dokaznog kredibiliteta prikupljenih dokaza te s tim u vezi utvrđivanja postojanja krivičnog djela i njegovog počinioca.

Sistem nezakonitih dokaza uvijek se i u svakoj državi razvija kroz sudsku praksu. Međutim, zbog njegove isprepletenosti sa zaštitom osnovnih ljudskih prava, ustavotvorac, odnosno zakonodavac nije mogao prepustiti pitanje upotrebe nezakonitih dokaza isključivo sucu, već je sudačkoj diskreciji postavio više ili manje čvrste granice.

Dok je dopuštanje korištenja dokaza izvedenih iz nezakonitih dokaza načelan stav primjerice engleskog ili njemačkog zakonodavca ( kroz sudsko vaganje interesa), korištenje takvih dokaza u Sjedinjenim Američkim Državama, iz kojih je doktrina ,plodova otrovne voćke“" proistekla, načelno je nedopušteno, ali je američka sudska praksa putem iznimaka koje se spominju u radu usvojila i izgradila stav u kojim je situacijama korištenje ,plodova otrovne voćke" u sudskom postupku dopušteno.

Krivično procesno zakonodavstvo u Bosni i Hercegovini je po uzoru na sistem apsolutnog izdvajanja nezakonitih dokaza prema doktrini preuzetoj iz Sjedinjenih Američkih Država prihvatilo apsolutno isključivanje nezakonitih dokaza iz sudskog spisa bez obzira da li se radi o izvorno nezakonitom dokazu ili dokazu koji je nastao kao derivat „plod“ nezakonitog

\footnotetext{
147 Odluka o dopustivosti i meritumu, AP 2635/09 od 28. septembra 2012., Službeni glasnik BiH, broj 94/12.

148 Odluka o dopustivosti i meritumu, AP 1158/10 od 28. februara 2013., Službeni glasnik BiH, broj 27/13.

149 Odluka o dopustivosti i meritumu, AP 2453/10 od 17. septembra 2013., Službeni glasnik BiH, broj 80/13.

${ }^{150}$ Odluka o dopustivosti i meritumu, AP 3364/10 od 12. februara 2014. Službeni glasnik BiH, broj 21/14 i Odluka o dopustivosti i meritumu AP 2400/11 od 24. aprila 2014., Službeni glasnik BiH, broj 79/14. O argumentima protiv stava Ustavnog suda da propust sudije za prethodni postupak da zabilježi tok razgovora i sačini prijepis zapisnika vid. više u: Ikanović, V. (2014.). Naredba za pretresanje na osnovu usmenog zahtjeva i zakonitost dokaza. Godišnjak Fakulteta pravnih nauka. Banja Luka, broj 4, str. 114-131.
} 


\section{LEGAL CONCEPT OF UNLAWFUL EVIDENCE IN CRIMINAL PROCEDURES IN BOSNIA AND HERZEGOVINA WITH REFERENCE TO COMPARATIVE LAW}

Summary: The paper discusses the legal concept of unlawful evidence in criminal legislation in Bosnia and Herzegovina from a theoretical, legal and practical aspect. After the theoretical explanation of the notion of "unlawful evidence", the positive legal provision on unlawful evidence in criminal proceedings in Bosnia and Herzegovina and the legal consequences of their use are analyzed with a comparative analysis of the legal concept in the most important legal systems of the European continental system and the Anglo-saxon legal circle (USA). The paper further points to the two most significant theoretical and comparative system for the exclusion of unlawful evidence - the absolute and the relative system of exclusion of unlawful evidence. In the last chapter, there is a comprehensive overview of the jurisprudence of the European Court of Human Rights and the Constitutional Court of Bosnia and Herzegovina on the issue of illegal evidence. By normative analysis of domestic legal norms on which the institute of unlawful evidence was founded, in establishing their exact meaning and sense, and by parallel comparison with comparative systems, with reference to the current court practice regarding the legal consequences of the use of unlawful evidence in criminal proceedings, the author ultimately - which is the aim of the paper, expresses its position and points to the necessity of changing the legislation when it comes to the absolute form of exclusion of unlawful evidence and standardizing the so-called relative exclusion based on proportionality, which is in line with the dominant trends in the development of this institute in comparative law.

Keywords: unlawful evidence, absolute and relative exclusion of unlawful evidence, proportionality, comparative law. 